\title{
MICROFINANCE AND HOUSEHOLD WELFARE
}

Cambodia Policy Note
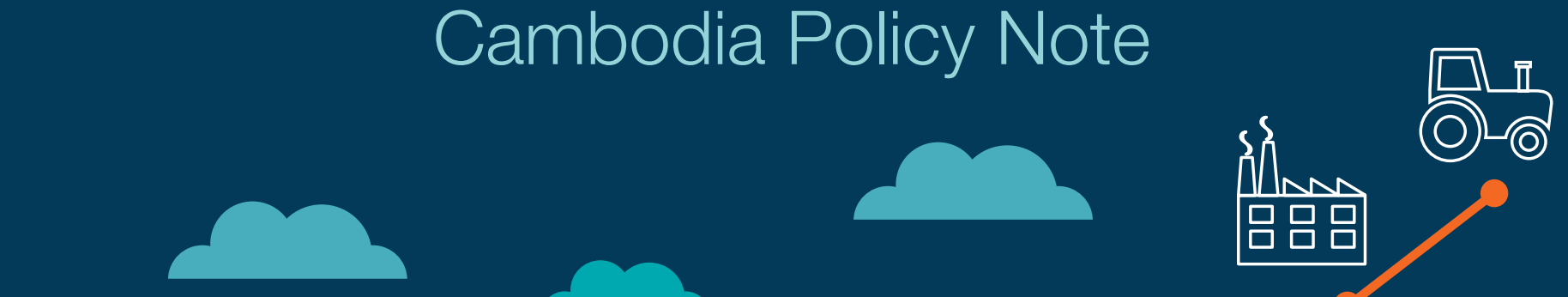

(8)

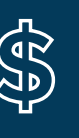

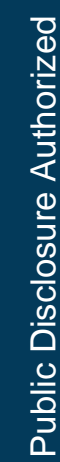
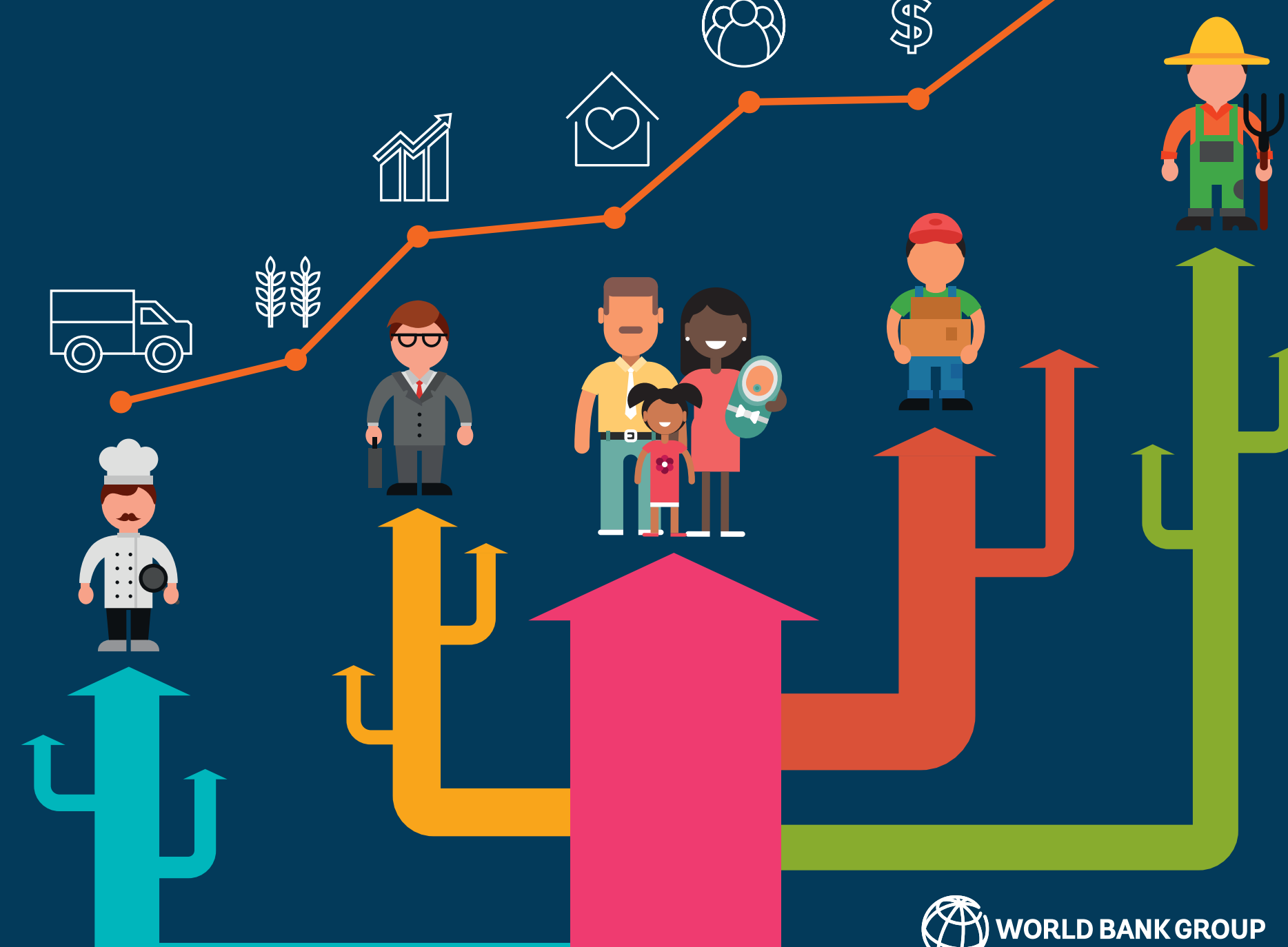
(C) 2019 International Bank for Reconstruction and Development / The World Bank

1818 H Street NW, Washington, DC 20433

Telephone: 202-473-1000; Internet: www.worldbank.org

Some rights reserved

123418171615

This work is a product of the staff of The World Bank with external contributions. The findings, interpretations, and conclusions expressed in this work do not necessarily reflect the views of The World Bank, its Board of Executive Directors, or the governments they represent. The World Bank does not guarantee the accuracy of the data included in this work. The boundaries, colors, denominations, and other information shown on any map in this work do not imply any judgment on the part of The World Bank concerning the legal status of any territory or the endorsement or acceptance of such boundaries.

Nothing herein shall constitute or be considered to be a limitation upon or waiver of the privileges and immunities of The World Bank, all of which are specifically reserved.

\section{Rights and Permissions}

This work is available under the Creative Commons Attribution 3.0 IGO license (CC BY 3.0 IGO) http:// creativecommons.org/licenses/by/3.0/igo. Under the Creative Commons Attribution license, you are free to copy, distribute, transmit, and adapt this work, including for commercial purposes, under the following conditions:

Attribution-Please cite the work as follows:

Pimhidzai, Obert; Tong, Kimsun; Anantavrasilpa, Ratchada; Popovic, Andrej; Mel, Sokim; Sanchez Martin, Miguel Eduardo, 2019. Microfinance and Household Welfare. Cambodia policy note. Washington, D.C.: World Bank Group.

Translations - If you create a translation of this work, please add the following disclaimer along with the attribution: This translation was not created by The World Bank and should not be considered an official World Bank translation. The World Bank shall not be liable for any content or error in this translation.

Adaptations - If you create an adaptation of this work, please add the following disclaimer along with the attribution: This is an adaptation of an original work by The World Bank. Views and opinions expressed in the adaptation are the sole responsibility of the author or authors of the adaptation and are not endorsed by The World Bank.

Third-party content-The World Bank does not necessarily own each component of the content contained within the work. The World Bank therefore does not warrant that the use of any third-party-owned individual component or part contained in the work will not infringe on the rights of those third parties. The risk of claims resulting from such infringement rests solely with you. If you wish to re-use a component of the work, it is your responsibility to determine whether permission is needed for that re-use and to obtain permission from the copyright owner. Examples of components can include, but are not limited to, tables, figures, or images. All queries on rights and licenses should be addressed to the Publishing and Knowledge Division, The World Bank, 1818 H Street NW, Washington, DC 20433, USA; fax: 202-522-2625; e-mail: pubrights@worldbank.org.

Cover design: Florencia Micheltorena, Buenos Aires, Argentina.

Interior photo: Chor Sokunthea / The World Bank. 


\section{MICROFINANCE AND HOUSEHOLD WELFARE \\ Cambodia Policy Note}

February 2019

(4) WORLD BANK GROUP 


\section{Foreword}

Thanks to rapid and sustained growth, Cambodia has become one of the world's leaders in poverty reduction and shared prosperity. Cambodia's success so far has ridden on openness to trade and investment, preferential trade treatment, and an abundance of low-skilled, low-cost labor. This facilitated the establishment of an export-oriented and foreign-owned garment sector, which - together with tourism, agriculture, and construction-has been driving growth over the past two decades.

Several factors suggest that Cambodia will not be able to rely on its current drivers of growth going forward. With the country becoming more prosperous, it is receiving less generous donor financing, and preferential trade treatment is expected to phase out eventually. At the same time, rising wages are making it increasingly difficult for Cambodia to keep exporting unprocessed rice and low-end garments. Meanwhile, around the globe, automation is displacing jobs, and digital technologies are transforming certain sectors. Coinciding with the possibility of diminished economic prospects are the rising expectations of Cambodian citizens, fueled by the rapid spread of information through mobile phones, the internet, and social media.

In light of these factors, Cambodia's current drivers of growth need to be diversified. While the country's economic outlook remains positive, Cambodia could begin to explore new drivers of growth that will create jobs and boost prosperity over the next 20 years. The country's next economic transformation will rest on its ability to empower domestic entrepreneurs and citizens with capabilities and tools for the modern economy of tomorrow.

Drawing from the knowledge gaps identified in the Cambodia Systematic Country Diagnostics, the Cambodia Policy Notes analyze four relatively under-analyzed policy areas: Entrepreneurship and Innovation, Digital Economy, Microfinance and Household Welfare, and Social Assistance. These topics are interrelated and will be crucial for catalyzing or complementing reforms in traditional sectors. For example, digital platforms are expected to play a key role in enabling local entrepreneurs to participate in global value chains more effectively. Financial technology (fintech) can provide expanded access to finance for both enterprises and individuals as well as facilitate the growth of e-commerce. Social assistance could help mitigate shocks for households and contribute to building a stronger human capital base to take advantage of new opportunities and safeguard the impressive economic gains of the last two decades.

Ellen Goldstein

Country Director for Cambodia, Lao PDR, and Myanmar

World Bank Group 


\section{Acknowledgements}

This Policy Note has been prepared by a World Bank Group team led by Obert Pimhidzai and Kimsun Tong, with contributions from Ratchada Anantavrasilpa, Sokim Mel, Andrej Popovic, and Miguel Eduardo Sánchez Martín. The authors are grateful to Swapnil Kant Neeraj, and Thuy Thu Bui for their feedback.

The note benefits from guidance provided by Ellen A. Goldstein, Inguna Dobraja, Irina Astrakhan, Salman Zaidi, Deepak Mishra, Shabih Ali Mohib, Mark Austin, and Lars Sondergaard. Minna Hahn Tong and Maria Dumpert helped edit the note.

The team is grateful to Cambodian government institutions for the support provided during preparation of this Policy Note. In particular, the team would like to thank H.E. Chea Serey (Assistant Governor and Director General of the NBC), H.E. Mey Vann (Director General, General Department of Financial Industry, MEF), H.E. Tep Phyorin (Director General, General Department of Economic and Public Finance, MEF), Mr. Em Kamnan (Director of Legal Department, NBC), Mr. Teng Tithanou (Deputy Director of Financial Market, MEF), Mr. Kith Sovannarith (Deputy Director General and Director On-Site Supervision Department, NBC), Mr. Lun Sam OI (Deputy Director of Off-Site Supervision Department, NBC), Mr. Men Pheakdey (Deputy Director of On-Site Supervision Department, NBC), Mr. Som Kossom (Division Chief of Off-Site Sup Department, NBC), and Ms. Mak Reaksmy (Division Chief of Legal Department, NBC).

The note benefited from the kind cooperation of the Credit Bureau of Cambodia, which provided access to some of the data used in the analysis. Further contributions were provided by private sector representatives, including Mr. Sovanna Yun (General Secretary, Cambodia Microfinance Association), who provided useful insights and feedback for the Note.

The team is also grateful to Da Lin for her support during team missions and stakeholder consultations.

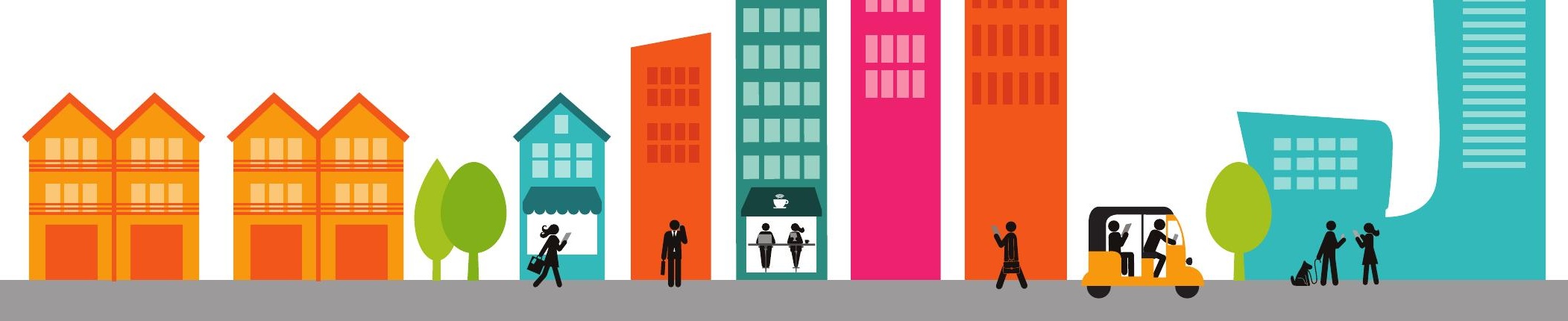


- At the same time, there has been a reduction in small loans in favor of larger loans with a longer time span, without necessarily slowing overall microcredit growth. Due to the introduction of the interest rate cap, the number of loans of USD 500 or less declined by 48 percent. Notably, the proportion of households in the first quintile (poorest) who borrowed from an informal source increased by 5 percentage points in 2017. Meanwhile, microfinance sector lending grew by 53 percent in the last 3 quarters of 2017 compared to a similar period in 2016, as loan size increased by an average of USD 1,200 and USD 240 for microfinance deposit-taking institutions (MDIs) and MFIs, respectively.

- To increase access to finance while minimizing risks, key policy priorities include: (i) introducing regulatory policies that enable reform of the operation and delivery models for MFls to increase their operational efficiency (including through digital distribution), (ii) addressing funding constraints in the microfinance sector, (iii) broadening financial instruments to meet household consumption borrowing needs, (iv) strengthening consumer protection and empowerment to enhance welfare impacts, and (v) improving transparency, lending practices, and supervision to reduce risks.

\section{Introduction}

\section{Cambodia's openness to trade and financial flows} fueled one of the fastest credit growth episodes in Asia, although Cambodia remains a predominantly cash-based economy. Capital account openness and dollarization led to rapid growth in foreign currency deposits, averaging close to 25 percent growth year-onyear since 2010. This fueled one of the fastest capital deepening episodes in the region, with Cambodia's credit to private sector as a percentage of gross domestic product (GDP) jumping from 2 percent in 1993 to 69.7 percent in 2016, already above the average for lower middle-income economies. A significant share of lending went to households, placing Cambodia among the top developing countries in terms of the percentage of people who borrowed money from a financial institution in 2017. However, only 5 percent of the population aged 15 and above saved at a financial institution, and just 50 percent withdrew money from an account during the past year-one of the lowest percentages in the world. ${ }^{1}$ Thus, Cambodia remains a predominantly cash economy, with people enjoying easy access to borrowing but with the majority of the population still being unable to save.

A remarkable expansion in formal microfinance lenders contributed to increased access to credit. Since the promulgation of the Policy and Strategies in the Microfinance Sector (2007), Cambodia's microfinance sector has expanded rapidly, with both assets and credit growing at annualized rates of over 40 percent. ${ }^{2}$ The number of MFIs in Cambodia increased from 16 in 2006 to 69 in 2017. In addition, Cambodia has 7 microfinance deposit-taking institutions (MDIs) and 170 registered microfinance operators. ${ }^{3}$ Between 2009 and 2017, the number of borrowers in the microfinance sector ${ }^{4}$ more than doubled to 1.8 million, three times the number of borrowers of commercial banks. Outstanding loans

1 Global Financial Inclusion Database.

2 Following the enactment of the Law on Banking and Financial Institutions in November 1999, Prakas No B7.00-06 outlined the process of MFI registration and licensing in Cambodia. The National Strategy for Microfinance, promulgated by the Prime Minister in 2007 , endorsed the role of microfinance in promoting businesses, increasing agricultural productivity, and ultimately improving the living standards of rural households and reducing poverty.

3 Prakas No.B7.02.49. Microfinance is defined as "the delivery of financial service such as loans and deposits to the poor and low-income households, and to micro-enterprises." MDIs provide loans and mobilize saving from general public, while MFls provide only loans. All non-government organizations, associations, and other entities engaged in microfinance are required to register or obtain a license if they meet certain thresholds detailed in the Prakas.

4 In this Policy Note, when referring to the microfinance sector both MFIs and MDIs are considered. 
grew from USD 640 million in 2011 to USD 4.2 billion in 2017. Notably, the seven MDls accounted for more than 85 percent of total customers and loan volume in the microfinance sector in 2017.

While access to credit helps ease financial constraints for households, one key concern is how the cost of credit and increased exposure to risk and debt levels might affect household welfare. At the household level, low financial literacy could result in poor borrowing decisions and heighten risks. Thus far, empirical studies on the impact of micro-credit on household welfare in Cambodia have been inconclusive. ${ }^{5}$ The ongoing policy debate has focused on determining whether households are overindebted, whether the market is saturated, ${ }^{6}$ what the motivations for borrowing are, and how to reinforce the positive aspects of microcredit while reducing the cost of credit, improving the quality of loans, and managing risks. In April 2017, Cambodian authorities introduced an interest rate cap aimed at lowering the cost of borrowing.

This policy note assesses the impact of access to credit on household welfare in Cambodia and provides evidence on the drivers of the cost of credit in the microfinance sector, as well as preliminary estimates of the impact of the interest rate cap. To fill the existing knowledge gaps, this policy note uses the latest available data from official sources to provide evidence on (i) the impact of microcredit on household welfare, (ii) profitability and cost of credit in the microfinance sector, and (iii) the effects of the interest rate cap in the sector. ${ }^{7}$ This note ultimately presents a series of policy options aimed at facilitating affordability and reducing the cost of credit, while maintaining sector profitability and minimizing risks for both households and the financial system. Policy options have been prepared in consultation with stakeholders.

\section{Context and Main Challenges}

\author{
The expansion of the microfinance \\ sector has provided access to \\ formal credit for a large segment \\ of borrowers who previously \\ depended on informal sources
}

While the share of households accessing credit has not changed significantly, expansion of the microfinance sector has made it possible for borrowers to shift from informal to formal sources of credit, especially among the poor. The share of households borrowing from formal sources increased from 8 percent in 2004 to 30 percent in 2017, while the share borrowing from informal sources decreased from 32 percent to less than 6 percent (Figure 1, left panel). ${ }^{8}$ Formal credit has expanded for a segment of the population who previously relied on unregulated private money lenders, although the overall share of households accessing credit has not changed significantly, hovering around 37 percent over the past decade. As access to formal credit has expanded, the population in the poorest quintile has become as likely to borrow from a formal source of credit as those who are better off (Figure 1, right panel). It is nonetheless worth noting that the proportion of households in the first quintile (poorest) who borrowed from an informal source increased by 5 percentage points in 2017 , which may suggest that some low-end clients turned back to informal sources after the interest rate cap was introduced in April 2017.

However, some pockets of financial exclusion remain. An analysis of household survey data conducted for this policy note found that borrowing from any source is highest in rural areas, where about

\footnotetext{
5 Phim, 2014; Roth, 2016; Seng, 2017.

6 Mimosa, 2016.

7 This analysis used the Cambodia Social-Economic Survey 2004-2016 and Propensity Score Matching to assess the welfare impact of microcredit, National Bank of Cambodia published data in Annual Supervision Reports 2011-2017 and the application of Data Envelopment Analysis to measure the efficiency of the microfinance sector, and Credit Bureau Cambodia data from January 2015 to March 2018 and application of Regression Discontinuity to analyze the effects of the interest rate cap.

8 These trends are broadly in line with those in the Global Findex Database, where the share of adults who borrowed from a financial institution (formal source) increased from 19 percent in 2011 to 27 percent in 2017.
} 
39 percent of households have a loan, followed by other urban areas (31 percent). It is lowest in Phnom Penh (13 percent). Households are equally likely to borrow from formal credit sources in rural and other urban areas, but access to formal credit differs according to household characteristics. Larger households and those with older household heads tend to borrow more from formal sources. Unmarried household heads, those without complete primary education, and households belonging to an ethnic minority are significantly more likely to borrow from informal sources, which highlights some exclusion challenges (Table 3 in the Annex).

\section{Access to credit has provided some welfare benefits to the poor}

Access to formal sources of credit has improved affordability through reduced interest rates and longer repayment periods. In 2017, reported monthly interest rates on loans from formal lenders were 1.7 percentage points lower than those from informal credit sources (Figure 2, left panel). This difference translates into an annual effective interest rate for formal loans that is 22.4 percentage points lower than that of informal loans. In the formal sector, average loan durations

Figure 1. While borrowers have shifted from informal to formal sources of credit, Cambodia's share of indebted households has not increased significantly over the last decade

Percentage of indebted households by source

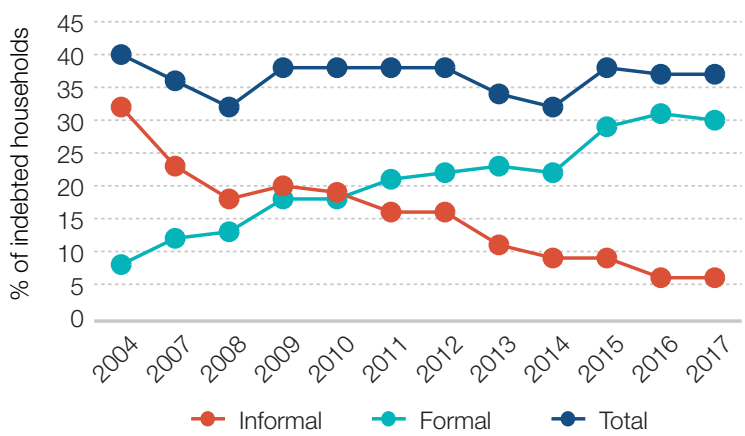

Source: Authors' calculation using CSES 2004, 2007-2017.
Source of loan by welfare quintile



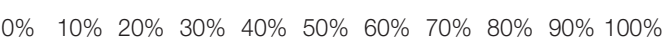

Informal $\quad$ Forma

Figure 2. Interest rates are lower for formal sources

Monthly interest rates (\%)

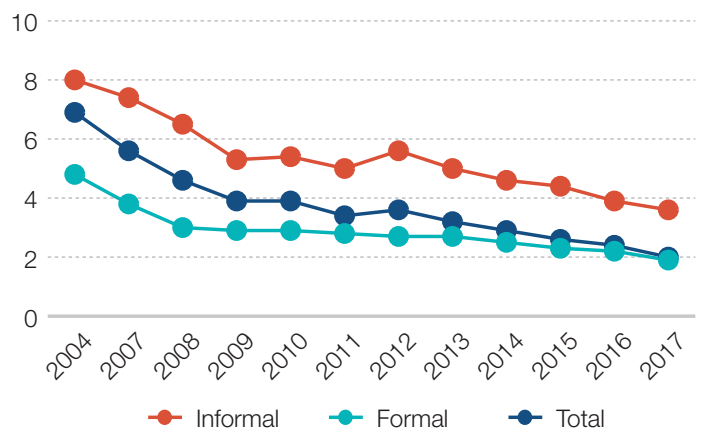

Source: Authors' calculation using CSES 2004, 2007-2017.
Loan duration (months)

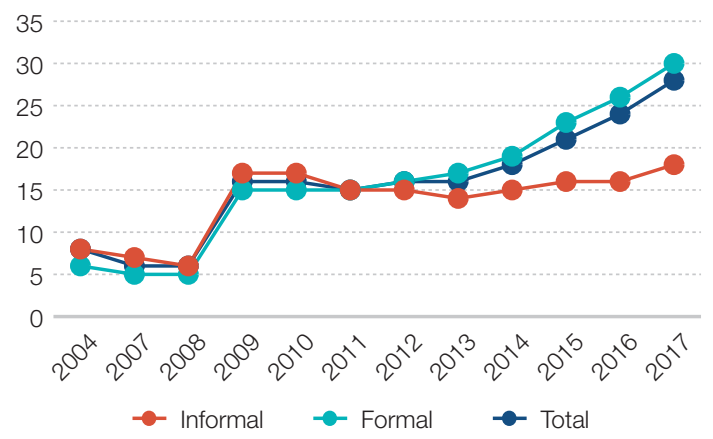




\section{Box 1: International evidence on the welfare impact of microfinance}

In Bangladesh, where comprehensive evaluations of microfinance have been conducted, findings on the welfare impact of microfinance have been mixed. The most comprehensive evaluation of microfinance, undertaken over 20 years by the World Bank, examined microfinance institutes in Bangladesh. The initial evaluation found that microcredit helped promote household welfare and that the impacts of credit are higher for women than men. ${ }^{1}$ While two follow-up studies have confirmed these benefits, ${ }^{2}$ they are not fully supported by others.

Mixed results have also been found in other countries, such as Bolivia, Ghana, India, Indonesia, Morocco, Peru, Thailand, and Sri Lanka. Studies on the impact of microcredit on households' socio-economic well-being found positive effects on the expansion of existing business enterprises, self-employment activities, and business profits; children's schooling; household welfare; and management of health and income shocks. ${ }^{3}$ However, there is also evidence that microcredit had little or no impact on consumption, health, women's empowerment, education, and business activities. ${ }^{4} \mathrm{~A}$ few other studies showed that microcredit reduced men's health expenditure, increased child labor, and worsened the borrowers' welfare. ${ }^{5}$

1 Khandker, 1998; Pitt and Khandker, 1996, 1998; Pitt et al., 1999; Pitt et al., 2006.

2 Khandker, 2005; Khandker and Samad, 2014.

3 Banerjee et al., 2014. Crepon et al., 2014; de Mel et al., 2008; McKernan, 2002. Islam and Choe, 2013. Imai et al., 2010; Imai and Azam, 2012;

Akotey and Adjasi, 2016. Gertler et al., 2008; Islam and Maitra, 2012.

4 Duflo et al., 2013; Crepon et al., 2014; Karlan and Valdivia, 2011.

5 Coleman, 1999. Maldonado \& González-Vega, 2008. Ganle et al., 2015.

increased from around 16 months in 2012, similar to the loan duration for informal credit at the time, to an average of 30 months in 2017. The extended loan tenure has allowed formal credit providers to offer larger loans, with a median of USD 2,000 in 2017, compared to USD 500 from informal sources. Another benefit of formal lending is a decreased chance of abusive interest collection practices. Assessed on these dimensions, the credit conditions faced by borrowers arguably improved with the switch to formal sources of lending.

\section{Some evidence indicates that microcredit has improved household welfare in Cambodia. Past}

studies in Cambodia have provided inconclusive evidence on the welfare impact of microfinance credit. ${ }^{9}$ Such contradictory findings are also evident in the international literature (Box 1). For this policy note, national household survey data was analyzed to compare various welfare outcomes for borrowing and non-borrowing households using improved statistical techniques. ${ }^{10}$ This analysis found that accessing a loan increased the chance of a household engaging in a household enterprise by 4 percent relative to similar households who did not have a loan in 2016. Similarly, households with a loan spent 5 percent more on agricultural inputs than those without a loan. The

9 Using panel data (2011-2014) for about 1,000 households in 11 villages in Cambodia and applying the difference-in-difference approach, Roth et al. (2016) concluded that microcredit increased paddy quantity and income, expenditure on inputs of paddy production, and non-land durable assets. Similarly, Phim (2014), also employing panel data (2001, 2004, and 2008) for 827 households and using a combination of propensity score matching and the difference-in-difference method, concluded that microcredit has a positive impact on poverty reduction. However, Seng (2017) used the nationally representative Cambodia Socio-Economic Survey in 2014 to examine the effects of microcredit on household welfare and found that both formal and informal microcredit reduced household expenditure.

10 Specifically, propensity score matching techniques were applied to nationally representative household survey data over several years to compare various welfare outcomes for borrowing and non-borrowing households that had similar financial capacities prior to the borrowing household taking a loan. 
analysis also found evidence of positive impacts in terms of health expenditure (for households with ill members), non-food consumption, ${ }^{11}$ and poverty reduction (Table 4 in the Annex). The findings suggest that microcredit has played an important role in developing entrepreneurial activities, commercializing agriculture, and improving the overall living standards of the poor.

However, risks may be increasing as the level of indebtedness rises and more funding is directed toward consumption

Household debt levels have increased significantly in recent years, as the average loan size has grown faster than household income. Official data from the Credit Bureau Cambodia shows that between 2015 and 2017, the average loan size in the microfinance sector grew by 80 percent, continuing a trend observed since the beginning of the decade. The ratio of outstanding debt to consumption (extrapolated over the loan duration) for borrowers in the bottom 40 percent (first two income quintiles) increased from 11 percent in 2010 to 33 percent as of 2017 . The increase in the ratio was more pronounced among the top 60 percent, from 9 percent to 43 percent over the same period (Figure 3 , left panel). While the share of households that borrow is higher among the bottom 40 percent (Figure 3, right panel), the debt-to-consumption ratio is higher in urban areas and among the top three quintiles. The quickly increasing debt-to-consumption ratio has raised concerns about the debt repayment capacity of a significant number of borrowers. These trends may be the result of intense competition in the microfinance sector, as well as the fact that in most cases, incentives are provided to credit officers based on volume of lending, without considering quality or risks.

Moreover, borrowing is being directed increasingly toward consumption needs that could have been met with different financial instruments. Loans devoted to agricultural and non-agricultural activities decreased from 47 percent of the total in 2004 to 29 percent in 2017 (Figure 4). Loans used for non-incomegenerating activities increased over the past decade largely due to a rise in housing improvement and durable goods acquisition loans, reaching more than two-thirds of the total in 2017. There are alternative financial products better suited to the purposes for which most of the non-income-generating loans in Cambodia are used. Loans used to cover health- and injury-related expenses (4 percent of total) and funeral expenses could be better financed in insurance markets; durable goods acquisitions could be funded using retail credit and installment arrangements; and housing improvement, weddings, and other lumpy expenditures

Figure 3. Average indebtedness relative to consumption has increased significantly in recent years

Borrower debt-to-consumption ratio



200920102011201220132014201520162017

$\rightarrow$ Bottom 40 percent $\rightarrow-$ Top 60 percent $\bullet$ - Rural areas $\bullet-$ Urban areas

Source: Authors' calculation using CSES 2004, 2007-2017.
$\%$ indebted households by quintile

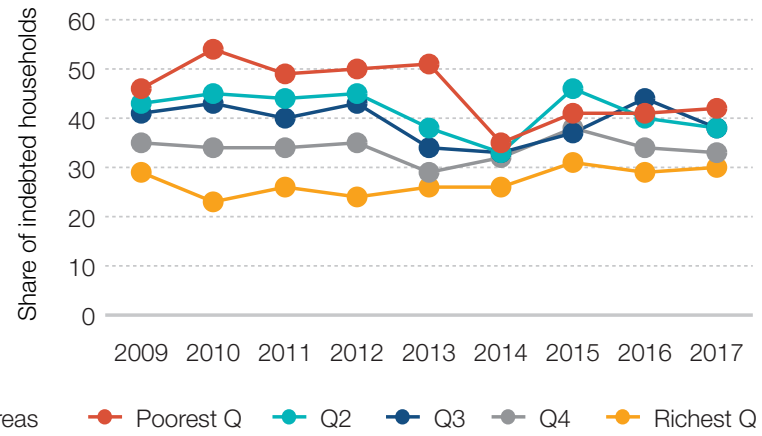

11 No significant impact on food consumption was observed. 
could be financed by innovative saving schemes. While some of these instruments already exist in Cambodia, their effective delivery remains an issue, since potential customers in many cases do not have the financial education needed to understand the advantages of insurance, and MFIs are not allowed to bundle these products together with microcredit. Low penetration or uptake of alternative financial instruments may lead to an avoidable increase in household debt burden and may also limit the role of microcredit in developing entrepreneurial activities. A companion Policy Note on Entrepreneurship and Innovation discusses challenges in access to finance for micro, small, and medium enterprises in more detail.

A rise in the share of overdue loans ${ }^{12}$ points to rising risks in the microfinance sector. As of end 2017, the share of reported NPLs had increased to 2 percent, still low by international standards. ${ }^{13}$ However, the share of loans with repayments more than 90 days overdue (portfolio at risk) has increased significantly for MFIs, reaching nearly 6 percent by mid-2017 before declining to around 4.5 percent in early 2018 (Figure 5, left panel). Another key issue from the asset quality perspective is the high percentage of refinanced portfolio in
Cambodia, which might result in repayment issues being underreported. ${ }^{14}$ To strengthen monitoring and mitigate potential risks, the National Bank of Cambodia passed a Prakas on Credit Risk Grading and Impairment Provisioning in December 2017 which includes a more comprehensive classification of portfolio at risk and mandates the provisioning of losses when a loan is past due over 180 days.

Although the average loan size by MFls is not substantially lower than loans by MDIs, MFIs in Cambodia make riskier loans. The loan portfolio of MFls comprises a higher share of personal loans (58 percent, compared to 21 percent for MDIs), which are riskier on average (Figure 5, right panel). Even for the same type of loans, delinquencies for MFI loans are significantly higher. This is consistent with the higher share of unsecured loans for MFls (16 percent) compared to MDIs (1.4 percent). MFls also have most of their loans secured by other types of titles (i.e. not land or immovable property titles). This pattern suggests that the quality of collateral for MFI loans is poorer, MFls have weaker repayment collection capacity, or risk assessment is limited, resulting in a higher portfolio at risk.

Figure 4. Loans used toward non-income-generating activities have increased
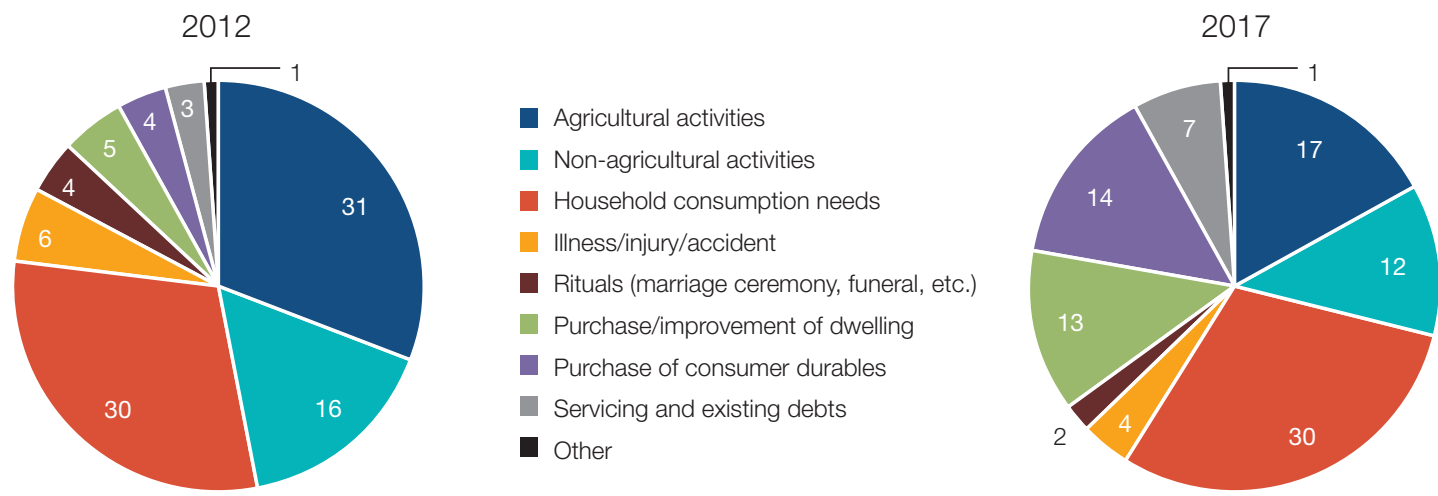

Source: Authors' calculation using CSES 2004, 2007-2017.

12 Portfolio at risk (PAR), the most accepted measurement of portfolio quality, is the outstanding amount of all loans that have one or more installments of principal past due by a certain number of days (e.g., 30 days or 90 days).

13 The NPL ratio is defined as the amount of NPLs (loans for which payments are more than 30 days overdue) divided by gross loan portfolio. The information is presented in the National Bank of Cambodia Annual Report for 2017.

14 Early refinancing with much larger loans and longer tenor, while conducting just a limited assessment on the repayment capacity of borrowers, has increased significantly. This causes potential repayment risk and deterioration of the portfolio. 
Figure 5. The portfolio at risk is significantly larger in MFls than in MDIs

Overdue loan and write off (value)

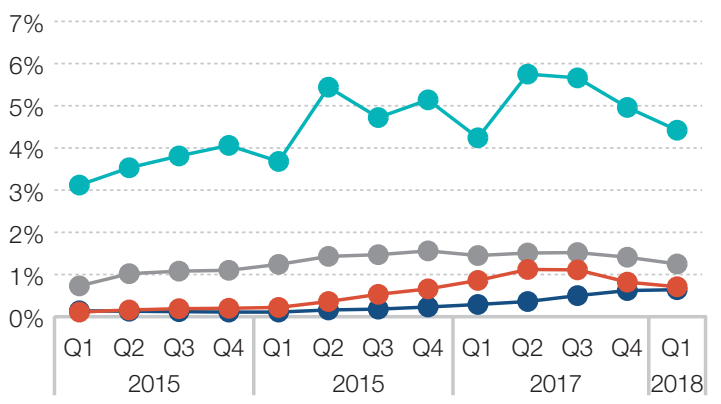

- MDI: of amount with overdue payment (>90 days) - MDI: write off - MFI: of amount with overdue payment (>90 days) $-\rightarrow$ MFI: write off

Source: Credit Bureau Cambodia.

Low financial literacy compounds the current challenges. Most poor borrowers are not informed enough to choose the right financing instruments. According to the 2014 S\&P Global FinLit Survey, only 18 percent of Cambodians could correctly answer three out of four questions related to basic financial literacy (risk diversification, inflation, numeracy, and compound interest). Acknowledging this challenge, the National Bank of Cambodia (NBC) is already making efforts to improve financial consumers' awareness of their rights and responsibilities through the "Let's Talk Money" campaign launched in 2015, which represents an important step in improving consumers' capacity for good financial decision-making.

The increasing debt-to-consumption ratios and deteriorating portfolio quality in the microfinance sector heighten Cambodia's macroeconomic risks. An important source of risk is that MFls (mostly MDIs) are borrowing in dollars from abroad, which results in currency mismatches (e.g., for activities that generate riel) and maturity mismatches (different loan length) and adds to external private sector debt. At the same time, smaller MFIs tend to borrow from domestic financial
Portfolio comparison

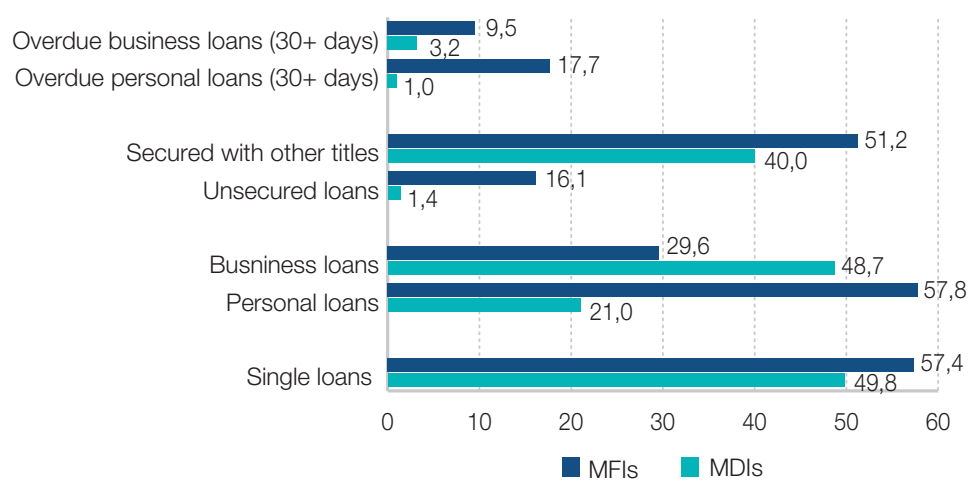

institutions, which mitigates foreign exchange risks but is also more costly; if the ultimate borrowers are not able to service their loans, the problem can easily spill over into the broader banking sector. An obsolete insolvency framework compounds these risks. The feasibility of potentially introducing deposit insurance to partly mitigate these risks needs to be assessed.

\section{Interest rates in microfinance remain high due to operational inefficiencies}

High operational expenses have kept the cost of providing credit in the microfinance sector high, while high interest expenses and loan losses place additional cost pressures on MDIs and MFIs, respectively. ${ }^{15}$ The average cost of credit in Cambodia-consisting of interest rate expenses, operating expenses, and loan losses - varies significantly across different types of lenders. At the lower end are commercial banks, with an estimated average cost of credit of 9.2 percent in 2016, followed by specialized banks at 14.3 and MDIs at 15.7 percent. MFls have the highest cost of credit at 22.5 percent in 2016 , since their

15 Cambodia's lowest microfinance lending rates have been 25 percent and 18 percent per annum in local and foreign currency, respectivelylower than those in Thailand (36 percent) but higher than in Vietnam (13.5 percent). The Thai government has capped the microfinance lending rate at 36 percent since 2014 (The Bangkok Post, 23 October 2013), and the Vietnamese government has also imposed a microfinance lending rate cap of 13.5 percent since 2012 (Vietnam Microfinance Working Group, 2013). In the Philippines, the interest rates have been between 6-20 percent per year (Philippine Daily Inquirer, 31 December 2015) 


\section{Figure 6. The cost of credit structure differs between MDIs and MFIs}

(a) Cost structure: $2011-2017$, $\%$ of loan volume

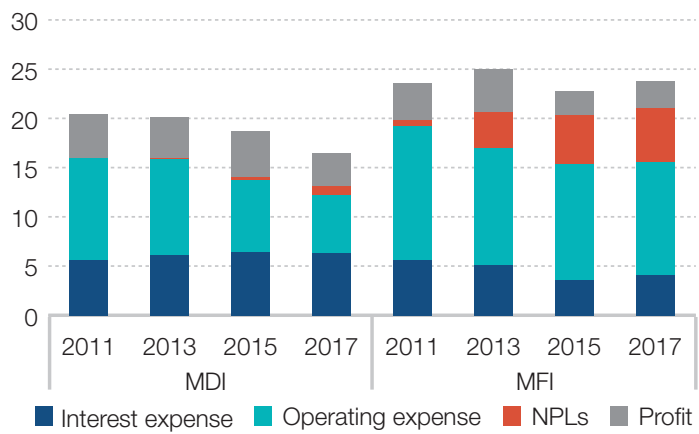

(b) Correlation between interest yield and cost of fund: 2012 - 2016

Source: Authors' calculation using National Bank of Cambodia data.

Note: Outlier MFIs with losses below 20 percent of their assets are excluded from the weighted average.

business model implies catering to rural and potentially riskier clients. MDIs are more leveraged, relying mostly on foreign capital, and interest expenses are around 40 percent of their cost of credit. MFIs are less leveraged but have much higher operating expenses, which indicates operational inefficiencies (Figure 6, left panel). ${ }^{16}$ Profits accounted for around 4 percentage points of the interest rate yield in recent years, which means that the cost of providing credit is the primary driver of high interest rates. A high correlation between the cost of providing credit and the interest rates charged has been found (Figure 6, right panel).

Inefficiencies due to misallocation of resources are the main driver of high operating costs in Cambodia. While the median operating expense ratio $(\mathrm{OER})^{17}$ in Cambodia is lower than the median values for the world and East Asia Pacific region, the cost per borrower is significantly higher than in any other region (Table 5 in the Annex). An efficiency benchmarking of microfinance lenders in Cambodia using data envelope analysis yields a technical efficiency score of 83 percent in 2016 and 2017 compared to 88 percent in 2012. Between 2014 and 2017, it appears that the efficiency of MDIs

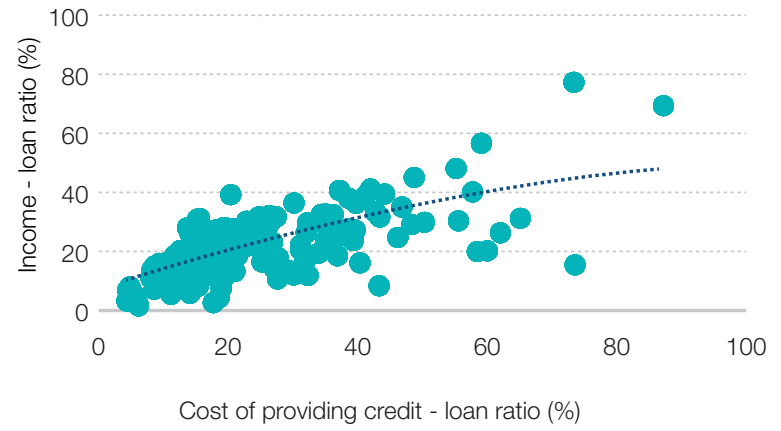

improved, while that of MFls decreased (Figure 9 in the Annex). There is scope for improving outcomes with the same amount of resources, especially among MFIs.

Econometric analysis of determinants of efficiency in the microfinance sector suggests that low staff productivity and administrative expenses are the most important determinants (Table 6 in the Annex). With a higher asset base and broader geographical coverage, larger MFls and MDIs tend to be more efficient. To a limited extent, higher equity investments, which can spur lenders into efficiency-seeking reforms as shareholders demand higher returns, are also associated with higher efficiency. The impact of interest expenses on efficiency is not robust, while foreign ownership is not a major determinant of microfinance lending efficiency in Cambodia. These findings suggest that redundant paperwork and processes and excessive use of labor are key drivers of the relatively high cost of providing credit in Cambodia, especially among MFls. Both redundant paperwork and processes can be largely attributed to underutilization of technology to provide credit at a lower cost. Interviews with MFIs suggest that some of them have streamlined paperwork

16 The sum of the median for the different components does not add up to the median for the total cost of credit.

17 The operating expense ratio (OER) is a commonly used indicator for measuring the cost efficiency of an MFI, defined as operating expense divided by average gross loan portfolio. The following benchmark was used to assess efficiency of the sample MFIs: Highly efficient = OER $\leq 25 \%$; Efficient $=$ OER $>25 \%$ to $35 \%$; Inefficient $>35 \%$ (ADB, 2012). 
and processes since the introduction of the interest rate cap, which may be related to some reduction in operating costs observed in 2017. However, this is not confirmed by the efficiency frontier analysis, since most changes were adopted in the second half of the year.

The high cost of funds adds to the cost of providing microfinance loans in Cambodia, especially for MDIs. The scaling up of macroprudential requirements introduced by the National Bank of Cambodia since 2016 has been a welcome step toward safeguarding financial sector stability. At the same time, the increase in deposit reserve requirements and liquidity buffers have raised the cost of funds for MDls, which have significant deposit amounts. The withholding tax on interest from loans acquired from abroad also adds to the cost of credit. A reduction in the tax from 14 to 10 percent, introduced by the Ministry of Economy and Finance in November 2017, has partly compensated for the increase in the cost of credit due to other macroprudential measures.

A structural challenge for most MFIs is the limited access to both domestic and foreign sources of funding. While domestic savings increased from an estimated 11.6 percent of GDP in 2011 to 16.7 percent in 2017 , they remain low by international standards. In addition, the domestic financial market remains fragmented and concentrated in retail markets with limited business-to-business interactions. As a result, MFls, which do not often enjoy access to international sources of funding, also face high cost of credit in the domestic market. Those microfinance lenders who borrow from international markets face high interest rates due to the high institutional and country risk premium.

\section{The interest rate cap reduced} issuance of small loans

\section{The recent introduction of the 18 percent interest} rate cap has put pressure on MFIs, which were already experiencing a fall in profitability. As of December 2016, before the introduction of the interest rate cap in April 2017, microfinance lenders charged interest rates ranging from 25-43 percent (for loans in $\mathrm{KHR}$ ) and 18-41 percent (for loans in USD).18 Yet the return on equity for Cambodian MFls has been lower than the regional and world averages (Table 1), and their return on assets has declined significantly since 2015. In contrast, Cambodian MDls - which are highly leveraged-have an astronomically higher return on equity than the world average and the averages for South Asia and East Asia and the Pacific, although it dropped significantly following the introduction of the interest rate cap.

The interest rate cap has resulted in the reduction of small loans in favor of larger loans but has not led to the expected slowdown in overall credit growth. Econometric estimates accounting for seasonal fluctuations 19 show that the number of loans of USD 500 or less declined by 48 percent after the introduction of the interest rate cap (Figure 7). Nonetheless, total microfinance lending increased by 8 percent largely due to a jump in the number of loans between USD 500-1000 and to some extent those above USD 1000 (Table 7 in the Annex). These estimates are backed by the NBC's annual supervision reports, which show an increase in total lending volume. Microfinance lenders thus responded to the interest rate cap mostly by increasing loan sizes and extending the repayment period. As mentioned above, the proportion of households in the first quintile (poorest) who borrowed from a formal source declined by 5 percentage points in 2017.

The interest rate reduction introduced by the cap has been partly offset by increasing fees. The average interest yield (interest income to loan ratio) decreased from 22.9 percent for MDIs and 21.7 percent for MFIs in 2016 to around 18 percent in 2017 after the introduction of the interest rate cap. To partly compensate for this, both

18 National Bank of Cambodia.

19 The introduction of the nominal interest rate cap on April 1, 2017, a structural break in the series, could be exploited to analyze the impact of the policy by comparing loan issuances immediately before and after the policy came into effect using regression discontinuity analysis. Given the high seasonality pattern of loan issuance in Cambodia, characterized by a dip in lending in the second quarter of the year, the analysis was done using seasonally adjusted figures. 
Table 1. Profitability in the microfinance sector varies significantly

\begin{tabular}{|c|c|c|c|c|c|c|c|c|c|c|c|c|}
\hline & \multicolumn{12}{|c|}{ Profitability (median) } \\
\hline & \multicolumn{6}{|c|}{ Return on Equity } & \multicolumn{6}{|c|}{ Return on Assets } \\
\hline & 2012 & 2013 & 2014 & 2015 & 2016 & 2017 & 2012 & 2013 & 2014 & 2015 & 2016 & 2017 \\
\hline World & 8.4 & 8.7 & 9.6 & 7.8 & 8.1 & NA & 1.8 & 2.0 & 2.0 & 1.9 & 1.8 & NA \\
\hline South Asia & 7.8 & 12.2 & 14.3 & 15.1 & 13.6 & NA & 1.5 & 2.2 & 2.5 & 2.5 & 2.5 & NA \\
\hline $\begin{array}{l}\text { East Asia and the } \\
\text { Pacific }\end{array}$ & 9.0 & 16.0 & 12.2 & 9.9 & 8.2 & NA & 1.9 & 3.5 & 3.0 & 2.6 & 1.6 & NA \\
\hline Cambodia MDIs & 20.0 & 21.5 & 23.7 & 29.4 & 25.4 & 13.8 & 3.4 & 3.3 & 2.9 & 3.3 & 3.1 & 2.2 \\
\hline Cambodia MFIs & 6.0 & 5.1 & 5.6 & 6.2 & 5.1 & 1.2 & 2.3 & 2.2 & 2.3 & 2.8 & 1.3 & 0.4 \\
\hline
\end{tabular}

Note: NA=Not available

Source: Authors' calculation using MIX Market (World, South Asia, East Asia and the Pacific) and National Bank of Cambodia data.

Figure 7. The interest rate cap reduced the smallest loans but increased total lending

(c) Average number of new micro-loans per commune

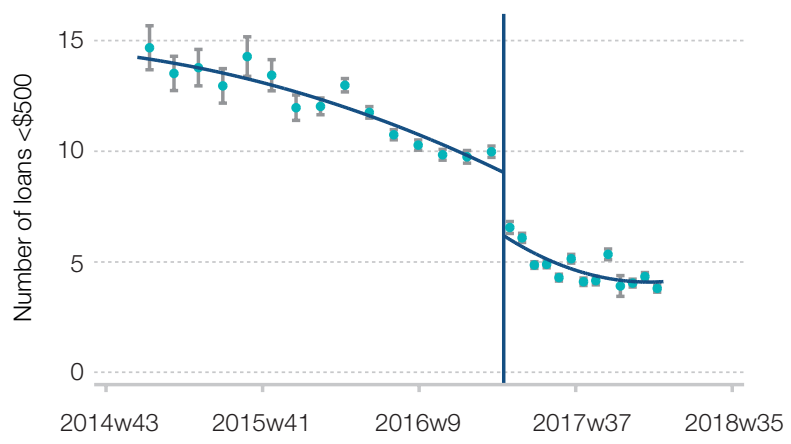

- Sample average within bin - Polynomial fit of order 2 (d) Average amount of new loans per commune

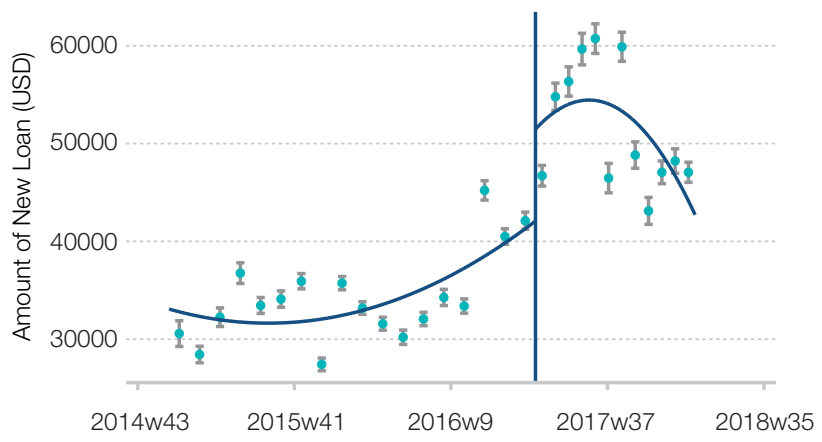

- Sample average within bin - Polynomial fit of order 2

Source: Authors' calculation using Credit Bureau Cambodia Data.

MDIs and MFls tripled their non-interest income to loan (mainly through fee increases) to 2.6 percent on average for MFls. Notably, most microfinance lenders previously lending at less than 18 percent (mostly MDIs) appear to have increased their interest rate upward, while those previously lending at above 18 percent (mostly MFIs) reduced their lending rates (Figure 8). As highlighted by the international experience, interest rate caps usually result in unexpected market distortions (Box 2).
Thus, average profitability in 2017 declined for MFIs, while it was sustained for MDIs. The mean net profit among MFIs dropped from USD 0.36 million in 2016 to USD 0.26 million in 2017. Meanwhile, average net profit for MDls increased from USD 16.9 million in 2016 to USD 17.8 million in 2017, compared to just USD 3.4 million in 2011. The percentage of MFls making losses increased from 26 percent in 2016 to 35 percent in 2017, while no MDls are making losses. 
Figure 8 . While interest rates decreased in 2017, this was partly offset by non-interest income

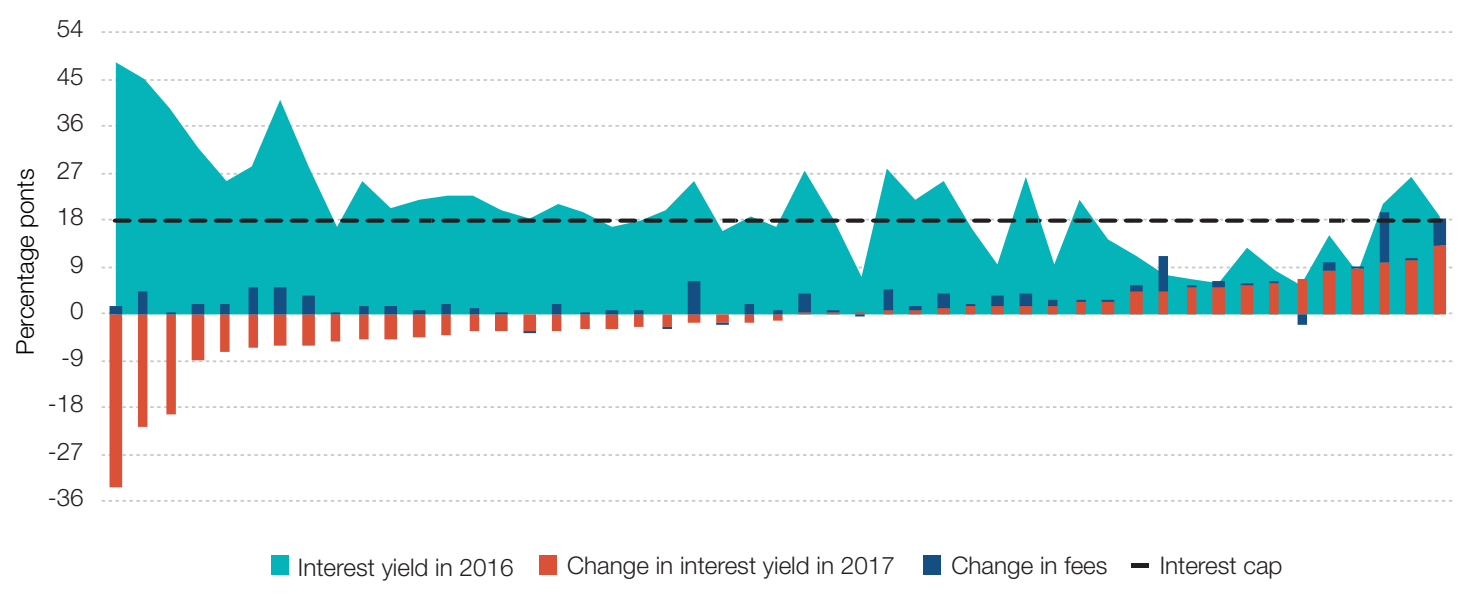

Source: Authors' calculation using National Bank of Cambodia, Annual Bank Supervision Reports: 2006- 2017.

\section{Box 2: The unintended effects of interest rate caps}

More than 75 countries, representing 80 percent of global GDP, have introduced interest rate caps with the aim of making credit cheaper and more accessible as well as protecting consumers from usury and exorbitant interest rates. These restrictions have taken many different forms, with some only affecting extreme pricing and others set at "binding levels" below market rates. In either case, the cap can be absolute (affecting all types of credit) or relative (varying based on the level of a benchmark rate). Rather than using a single limit, countries can also choose to set different caps based on the size or type of loan, type of financial institution, socio-economic characteristics of the borrower, or the industry. For example, Australia and Canada regulate payday loans, Nigeria has ceilings on mortgage rates, China has applied caps on MFI loans, and Vietnam has special rules for agricultural lending.

However, interest rate caps often have substantial unintended effects, such as increases in non-interest fees, lower credit supply and loan approval rates for small and risky borrowers, and fewer institutions. For instance, when rates in Kenya were capped at 14 percent in 2016 (below the average of 18 percent), the average annual percentage rate (APR) rose to 18.5 percent, increasing the effective cost of loans. Therefore, some countries also regulate non-interest costs, such as Thailand's 28 percent ceiling that includes both interest and fees. Low caps, however, may also result in reduced quantities of credit, given the high elasticity of credit supply to price changes, particularly for high-risk borrowers. For example, in Bolivia, the number of borrowers decreased by about 35,000 within two years after the introduction of interest rate caps in August 2013. Moreover, the credit market growth rate slowed to 16 percent per year, and importantly, the credit growth of small and medium enterprises became negative. 


\section{Box 2: continued}

As a result, many countries have recently repealed or reformed their restrictions on interest rates. In 2013 , Zambia introduced tiered caps for development MFls, regular MFls, and other financial institutions - all at levels below prevailing market rates - but repealed them in 2015 due to the negative effects they had on credit availability and fees. During this time, MFI credit growth dropped from 63 percent to 38 percent, while the ratio of fee income to interest income increased from 5.8 percent to 18 percent. Other countries that have repealed their restrictions include Argentina, which announced the elimination of all caps for credit operations in 2016, and China, which removed all restrictions on commercial lending rates in 2013 and scraped controls on deposit rates in 2015.

Given these negative side effects, alternatives and complementary measures for reducing the cost of credit should be considered. These measures, which should be based on the initial source of the distortion, may include: (i) fostering competition, if incumbent financial institutions have significant market power that allows them to profit by setting elevated rates; (ii) strengthening regulatory and supervisory capacities, if limited competition is due to legal and institutional weaknesses rather than collusive behavior; (iii) promoting the creation of credit bureaus, if the reason for high interest rates is information asymmetry; (iv) improving the efficiency of loan foreclosure procedures that allow banks to limit the losses from borrower default; and ( $v$ ) promoting consumer protection and financial literacy, if the aim is to protect consumers from usury rates. In some cases, a holistic macroeconomic solution may be required, which includes effective fiscal and debt management frameworks as well as capital market development.

Source: Based on Ferrari et al., 2018.

\section{International Experience}

International experiences point to potential solutions for tackling challenges such as operational inefficiencies and lack of alternative financial instruments. Cambodia can learn from international experiences on fostering product innovation and better delivery of microfinance to lower costs, improving regulations to maintain lending standards and reduce risks, and building the financial literacy of the population to make informed borrowing choices. For example, agent-based banking can reduce costs by using a network of agents to handle loan disbursement, repayments, and acceptance of deposits. A case study of FINCA in the Democratic Republic of Congo shows that a single transaction at an agent was 50 percent cheaper than an in-branch transaction. ${ }^{20}$ MFIs can also leverage mobile banking platforms for savings mobilization, loan disbursement, and repayments with reasonable investments in middleware to automate uploading and reconciling of repayment data. This section focuses on the experiences of the Philippines and Kenya in supporting digital financing to innovate on new business models - for example, using mobile banking for loan origination, application, and due diligence. ${ }^{21}$

\section{The Philippines - Policy and Regulatory Environment for Microfinance}

The policy and regulatory environment for microfinance in the Philippines is considered

20 Cazacu et al., 2016.

21 For further details, refer to Kumar et al., 2010; Metre, 2011; and Hanouch and Rotman, 2013. 
among the best in the world. For example, the Consultative Group to Assist the Poor (CGAP) declared the Philippines' microfinance industry as "the best in implementing programs to reduce poverty" during the International Year of Microcredit, 2005. More recently, the Philippines was ranked as one of the top five in the world in terms of policy and regulatory framework. ${ }^{22}$ The basic policy framework for the microfinance industry in the Philippines has been the National Strategy for Microfinance, which moved from direct credit and subsidized funding to a market-based orientation, using government funds for capacity building purposes and emphasizing savings mobilization. The Philippines has also encouraged MFls to take full advantage of technology (i.e. internet and mobile phone) and ensured that regulations on electronic banking are up to date. The authorities have also considered setting up an appropriate performance standard for microfinance. These initiatives offer useful examples for strengthening Cambodia's microfinance sector to support the use of technology, alternative delivery mechanisms, and improved standards.

\section{Kenya - Mobile Banking Services}

The most successful mobile banking service is M-PESA in Kenya, which allows customers to make cash withdrawals, deposits, and transfers using mobile phones. The main objectives of this service are to reduce low-value transaction costs, extend financial services to remote areas, and increase customer convenience by relying on agents instead of bank branches. The initial concept began as a pilot project in 2003 to test a mobile phone-based solution for processing financial transactions in remote areas of Kenya. Having successfully completed the pilot project, a mobile phone operator (Safaricom) and a commercial bank (Equity Bank) launched M-PESA in 2007, with the main purpose of providing remittance services. However, one-fifth of M-PESA customers also used the service as the main tool for saving. For this reason, the Central Bank of Kenya allowed an interest-collecting savings account to be set up with Equity Bank through Safaricom's mobile network. These savings accounts do not have account opening fees, minimum balance requirements, or monthly charges. Only three years after the launch, 9.5 million customers had registered for M-PESA, representing more than 45 percent of Kenya's adult population and twice the number of Kenyans with bank accounts.

Cross-country studies have found that digital finance can benefit both borrowers and lenders. A 2013 study on mobile banking shows that MFI customers valued the time and cost savings of mobile banking services for loan repayment. ${ }^{23}$ This was mainly because agents were more accessible than the MFI branches. For MFls, mobile banking could lower the cost of funding via deposits mobilized from customers, and these costs would be passed back to customers in the form of lower interest rates. Mobile banking also creates opportunities for an innovative microfinance business model to process loan applications by using transaction history (i.e. initial savings, loan repayment, and saving patterns) as the key tool. This lending model does not require loan officers to visit the client's house for credit decisions, which would reduce the burden on loan officers and operating costs. It can therefore increase staff productivity, which is a primary driver of operational costs in Cambodia.

\section{Policy Options}

A series of policy measures could help continue the expansion of access to credit to the most vulnerable groups, while lowering costs and improving lending standards in Cambodia. These measures could include (i) introducing regulatory policies that enable reform of the operation and delivery models for MFls to increase their operational efficiency and reduce the cost of providing credit, (ii) addressing funding constraints to the microfinance sector, (iii) broadening financial instruments

22 Economist Intelligent Unit, 2012-2016.

23 Hanouch and Rotman, 2013. 
to meet household consumption borrowing needs, (iv) strengthening consumer protection and empowerment to enhance welfare impacts, and (v) improving transparency, lending practices, and supervision to reduce risks. These areas resonate with the key strategic areas laid out in the Financial Sector Development Plan 2016-2025 regarding strengthening law enforcement and supervision of financial activities, enhancing financial literacy and consumer protection, seeking low funding sources, identifying the factors that contribute to high costs of funds, and finding ways to reduce interest rates with market mechanisms. Policy options in these areas are discussed in greater detail below.

Most of the policy options are cost neutral from a budget perspective, since they require mostly regulatory changes but not significant investments. The exceptions are the medium-term items on establishing e-Government and financial sector systems, in areas (i) and (ii).

\section{Improve the efficiency of MFIs by reducing operating costs}

MFIs in Cambodia can improve operational efficiency by adopting measures that increase the productivity of staff and reduce the costs of decentralized delivery to expand outreach. Such measures would include supporting the optimization of business processes (including through leveraging technology) and adopting innovative delivery models to reduce the costs of distribution and increase outreach. Evidence across the world shows that MFls sometimes fail to improve efficiency because inefficiencies might remain hidden in a high-growth environment-as is the case in Cambodia - as lenders focus on portfolio growth and expand to underserved markets. ${ }^{24}$ Furthermore, microfinance clients at times struggle to determine and compare prices, thus reducing competition on product quality and keeping prices high. Increased competition on product service quality and earnings pressure driven by higher-equity investments in MFIs can drive lenders to undertake efficiency-enhancing reforms.
Government policies to promote transparency, foster competition on service quality, expose inefficiencies, and increase investor demand for higher returns could spur efficiency-enhancing reforms. Such policies must be complemented by infrastructure investments and regulations that incentivize and are supportive of innovative efficiencyenhancing delivery mechanisms and reduce operating costs for lenders.

In the short term, MFIs can reduce operating costs by optimizing processes in four areas. First, processes can be streamlined to reduce low-value activities and paper movement, forms can be simplified, and redundant functions should be eliminated, especially in the credit assessment and approval processes. Second, centralization of processing functions can reduce efficiency losses. This would reduce costs significantly and improve quality compared to a decentralized delivery method in which branches autonomously undertake all credit processing functions (including credit approval), resulting in complex branch structures with high numbers of staff. Third, the credit scoring process can be standardized and automated to reduce time spent on credit assessment and the number of staff involved, while shifting to risk-based assessment.

Meanwhile, authorities should introduce a framework and clarify regulations for the use of electronic banking, mobile banking, and agent-based banking in the microfinance sector. Mobile financial services are being adopted around the world as a cost-effective mechanism for banks and other financial institutions to reach new customers rapidly without needing new physical branches. Cambodia does not have defined guidelines or requirements for the adoption of mobile banking in the microfinance sector, which is assessed on a case-by-case basis. Similarly, agent-based delivery models can help reduce transaction costs while expanding reach to remote areas. While some actors in the microfinance sector are using Wing or TrueMoney to collect debt service payments (Box 3), the adoption

24 Cazacu et al., 2016. 


\section{Box 3: Can digital finance be the answer for Cambodia?}

Recognizing the significant flows of business transactions and remittances (largely dominated by physical transfers) between Cambodia's rural and urban population, Wing has introduced digital banking services. Overall, 80 percent of Cambodia's population lives in rural areas, and only around 20 percent of adults have access to financial services (World Bank Global Financial Inclusion: Global Findex 2014). Taking this opportunity, Wing introduced digital banking services -initially offering local money transfers using mobile phones and point-of-sale (POS) devices in 2009, then more recently diversifying to phone top-up, bill payment, online payment, payroll, and international money transfers. In 2014, Wing's transaction amounts reached USD 4.5 billion with an estimated 1.5 million customers, of which 67 percent are in rural areas and 37 percent are women. Compared to the 1.9 million borrowers and 2.3 million depositors of MFls, Wing has become a leading player in financial inclusion in Cambodia.

Other commercial banks or microfinance institutes such as ACLEDA Bank, AMK, AMRET, and LY HOUR are also increasingly using technology and agents to serve their customers. Differing from other players, AMRET attempts to target different customers - mainly smallholder families - by developing digital goal-based savings (i.e. saving for a specific purpose such as the purchase of cows, child's education, or child's wedding), which allow family members to link their individual accounts so they can transfer money without transaction costs or can save jointly.

of agents is being approved on a case-by-case basis, with no clear rules guiding the process. Authorities should provide a guiding framework and, if needed, adopt secondary regulations that facilitate the adoption of these innovative delivery models while protecting customers.

Investments to support e-Government systems, including biometric IDs, would help enhance credit assessment and financial transactions. Investing in integrated digital information management systems with backend functions integration would help optimize processes by staff and facilitate the centralization of core activities such as credit approvals. Government investments in areas such as an updated digital land registry, a functional civil registry, and biometric IDs would facilitate the linking of information for individuals, land, and credit history, which would help improve credit scoring to enhance risk assessment as well as speed up transactions and reduce costs. Adopting the laws on Cybercrime and Electronic Commerce would also be crucial to unleash the potential of electronic financial services.

\section{Address MFI funding constraints by minimizing regulatory impact and diversifying sources}

Another way to reduce the cost of credit is by addressing funding constraints to the microfinance sector, which may require optimizing the impact of existing regulations. MDIs can leverage domestic deposits as a source of capital, but the existing liquidity coverage requirements add to the cost. When accessing funds from abroad, both MDls and MFls end up in practice facing the cost of a withholding tax that would in principle be charged to the foreign investor or lender. Authorities could conduct an assessment aimed at identifying measures to optimize liquidity requirements and taxation on foreign capital. In addition, authorities could assess the feasibility of establishing a microfinance apex institution ${ }^{25}$ that could

25 As discussed in Forster et al. (2012), "an apex is a second-tier (or "wholesale") fund that channels resources to multiple retail financial providerstypically lenders - in a single country. Apexes provide mainly local currency loans, but may also offer loan guarantees, equity investment, grants for operational cost support, and technical assistance." 
provide long-term wholesale funds in local currency to MFIs as well as, potentially, technical assistance (see Forster et al., 2012).

In the medium to long term, developing domestic capital markets and further building the financial system can help diversify the sources of financing and reduce funding costs. Currently, capital markets in Cambodia are underdeveloped, which limits the saving and investment options available to economic agents. Developing the legal and institutional framework for a domestic debt market and starting to issue sovereign debt would help provide a benchmark for private sector corporate debt issuances, which could be another source of financing for the microfinance sector. Cambodia would also benefit from implementing a National Payment System, which would allow for reliable and real-time payments and settlements and could be used by different actors, ultimately supporting the financial sector as well as broader economic development. Concurrently, financial infrastructure such as a good accounting system, reliable reporting system, sufficient disclosure, strong governance system (both public and private), court systems, and reliable insolvency regime should be built. The Financial Sector Development Strategy 2016-2025 is a good starting point for this long journey of financial sector development and must be implemented with the full engagement of all stakeholders to achieve success.

\section{Broaden financial instruments to meet households' borrowing needs}

Going forward, the focus of the microfinance sector in Cambodia could shift from credit-led growth to microinsurance, and new products could help facilitate an increase in deposits and remittances. To provide appropriate products to meet households' diverse borrowing needs, authorities need to develop secondary regulations that facilitate financial innovation while protecting customers. While health and funeral insurances already exist in Cambodia, distribution of these types of products remains limited. Currently, the bundling of financial and insurance products is not allowed, which reduces their uptake. The regulating bodies for both markets could discuss and agree on how to best establish procedures and complaint resolution mechanisms that are streamlined and satisfactory for financial and insurance products offered in a package. In addition, authorities could facilitate the development of new products aimed at channelling remittances from migrants and targeting other savings for education and lifetime events such as weddings and retirement.

\section{Strengthen consumer protection and empowerment to reap the benefits of microfinance while reducing household vulnerability}

To maximize the benefits of microfinance while reducing household vulnerability, borrowers need to be protected as well as empowered to optimize their financial decisions. The rise of new delivery mechanisms raises new challenges for consumer protection, while predatory lending practices leave households worse off and raise systemic risks. Consumer capacity should be enhanced so consumers can better choose among lending options-from discerning the most attractive terms across lenders to selecting the appropriate financial products for their needs, recognizing the risks and repayment limitations. The National Bank of Cambodia has taken some important steps toward improving financial consumer protection (FCP) in recent years, including the creation of an FCP unit, the establishment of an in-house consumer hotline, and the adoption of regulations on resolution of complaints about financial institutions. The launch of the "Let's talk money" campaign and the integration of financial education in the formal education curriculum are significant steps toward strengthening financial literacy. Some additional policy options are proposed below.

Given its immediate impact, strengthening consumer protection should be a short-term policy priority. In the short term, a financial protection law or consumer protection law with explicit reference to financial services should be adopted to help shield borrowers from predatory lending practices. It would also be beneficial to expand access to enable more people to 
use deposits, in conjunction with the development of an action plan for establishing an autonomous deposit protection institution to provide guarantees for deposit accounts in regulated financial institutions, thereby enhancing public trust in the banking system. Additional medium-term measures include implementation of equal treatment requirements; development and implementation of consistent, mandatory, binding, and enforceable external dispute resolution (EDR) schemes; and establishment of specialized complaint handling units. In the age of big data and digital finance, strengthening data protection would also be critical.

These efforts can be complemented with measures aimed at strengthening financial literacy. Authorities can build on the current financial literacy campaign and update the curricula to cover financial planning, exposure to new products, and borrower rights. Potential borrowers should be walked through the customer information sheet to help them understand the different interest rates and fees that add to the cost of credit. This should be complemented with dissemination of financial planning toolkits, such as easy-to-use financial calculators, that prospective borrowers could use to compare the financial implications of different loans or products.

Improve transparency, lending practices, and supervision to reduce risks

Managing risks and containing NPLs are a key part of reducing the cost of credit in Cambodia, especially among MFIs which have a riskier portfolio. Excessive risk lending behaviors that can result in deteriorating loan portfolio quality should be discouraged. Increasing accountability and reporting in the sector to expose hidden inefficiencies and systemic weaknesses is also important. Tighter supervision, stricter enforcement of regulations, and harmonization of regulatory and licensing requirements are therefore required.

First, sector supervision should be enhanced, including by fully implementing and closely monitoring the new Prakas on Credit Risk Grading and Impairment Provisioning. Supervision would focus on systematic monitoring of business practices in relation to payment, credit, and savings products, as well as on assessing compliance with macroprudential measures. Tighter supervision should be complemented by rigorous application of pre-announced and graduated sanctions on non-compliant institutions. The NBC can make regular use of off-site data analysis as part of its monitoring and supervision activities.

Second, regulatory requirements and licensing requirements are needed for the variety of actors providing microcredit. Currently, some micro-lenders such as NGOs and pawn shops are licensed under the Ministry of Interior and Ministry of Economy and Finance, respectively, and fall outside the regulatory supervision of the NBC. Licensing and supervision regulations should be revised to strengthen the NBC's mandate for financial consumer protection across microfinance providers. This would help curb unfair practices and ensure a level playing field for all actors.

Finally, for mitigating risks, adopting lending guidelines for the microfinance sector can be a good complement to macroprudential measures. A shortterm priority would be for sector actors to agree on a code of conduct and common lending guidelines that can help prevent predatory and risky lending practices. A concrete measure that could be introduced is common incentives for credit officers that are linked not only to lending volume (which has led to the explosion in loan size) but also to the number of customers and portfolio quality (NPLs). In addition, limits on loan size to income and refinancing could be established. Banks who operate in the microfinance sector should be subject to the same lending practices. In the medium to long term, the Cambodia Microfinance Association, in which all sector actors must be registered by law, could be empowered to develop and enforce self-regulation, which would require greater resources and capacity building. This would help alleviate the NBC's oversight burden and would ultimately render some restrictions such as the interest rate cap unnecessary. 
Table 2. Summary of policy options

Objectives

Short-term options (1-2 years)

i. Improve the efficiency of microfinance institutions by reducing operating costs

ii. Addressing funding constraints to microfinance institutions by minimizing regulatory impact

iii. Broaden financial instruments to meet households' borrowing needs

iv. Strengthen consumer protection and empowerment to reap the benefits of microfinance while reducing household vulnerability

v. Improve transparency, lending practices, and supervision to reduce risks
- Introduce a framework and clarify regulations on the use of electronic banking, mobile banking, and agentbased banking in the microfinance sector

- Optimize processes to reduce operating costs

- Evaluate the impact of liquidity requirements and taxation on the cost of funds for financial institutions

- Consider the feasibility of introducing a microfinance apex institution that could provide long-term funding

- Promote savings through innovative products aimed at capturing remittances and targeting lifetime events

- Enhance financial literacy outreach by focusing on financial planning, exposure to new products, and borrower rights

- Deploy easy-to-use and accessible financial planning and compliance verification toolkits

- Adopt a Consumer Protection Law, with explicit reference to financial services

- Implement the Prakas on Credit Risk Grading and Impairment Provisioning

- Harmonize regulatory requirements and licensing requirements for micro-credit actors (including pawn shops and rural credit providers)

- Adopt a code of conduct and lending guidelines for the microfinance sector
Medium- and long-term options (3+ years)

- Invest in supporting e-Government systems, including digital ID to enhance credit assessment

- Set up systems and regulations to develop domestic capital markets

- Implement the national payment system strategy

- Establish a deposit protection institution

- Implement consistent, mandatory, binding, and enforceable external dispute resolution schemes

- Empower financial sector associations to develop and enforce self-regulation 


\section{References}

Asian Development Bank. Microfinance Development Strategy 2000: Sector Performance and Client Welfare. Manila: Asian Development Bank, 2012.

Akotey, Joseph Oscare, and Charless K.D. Adjasi. Does Microcredit Increase Household Welfare in the Absence of Microinsurance. Vol. 77, World Development, 380394. Amsterdam: Elsevier, 2016.

Banerjee, Abhijit, Esther Duflo, Rachel Glennerster, and Cynthia Kinnan. The Miracle of Microcredit? Evidence from a Randomized Evaluation, Working Paper, Boston: MIT, Department of Economics, 2014.

Cazacu Diana, Tatyana Dolgaya, Till Bruckner, Michael Kortenbusch. Potential for Cost-Reducing and Efficiency - Increasing Measures in Financial Institutions. Frankfurt: KfW Development Bank, 2016.

Chantanusornsiri, Wichit. "Maximum rate for microfinance at 36\%," The Bangkok Post, October 23, 2013. http://www.bangkokpost.com/business/ news/375909/maximum-rate-for-microfinance-at-36

Colman, Brette E. The Impact of Group Lending in Northeast Thailand. Vol.60, Issue 1, Journal of Development Studies, 105-141. Amsterdam: Elsevier, 1999.

Crepon, Bruno, Florencia Devoto, Esther Duflo, and William Pariente. Estimating the Impact of Microcredit on Those Who Take it up: Evidence from a Randomized Experiment in Morocco. Boston: Department of Economics, MIT, 2014.

de Mel, Suresh, David McKenzie, and Christopher Woodruff. Returns to Capital in Microenterprises: Evidence from a Field Experiment, Policy Research Working Paper. Washington, DC: World Bank, 2008.
Duflo, Esther, Abhijit Banerjee, Rachel Glennerster, and Cynthia G. Kinnan. The Miracle of Microfinance? Evidence from a Randomized Evaluation, Working Paper. National Bureau of Economic Research, 2013.

Economist Intelligence Unit. "Global Microscope on the Microfinance Business Environment." Accessed March 6, 2018. www.eiu.com

Ferrari, Aurora, Oliver Masetti, and Jiemin Ren. Interest Rate Caps: The Theory and The Practice. Policy Research Working Paper, No. 8398. Washington, DC: World Bank. 2018

Forster, Sarah, Eric Duflos and Richard Rosenberg. A New Look at Microfinance Apexes. Focus Note, Consultative Group to Assist the Poor (CGAP), 2012.

Ganle, John Kuumuori, Kwadwo Afriyie, and Alexander Yao Segbefia. Microcredit: Empowerment and Disempowerment of Rural Women in Ghana. Vol.66, World Development, 335-345. Elsevier, 2015.

Gertler, Paul, David I. Levine, and Enrico Moretti. Do Microfinance Programs Help Families Insure Consumption Against Illness? Vol. 18, Health Economics, 257-273. Boston: Institute for Economic Development, Boston University, 2008.

Hanouch, Michel, and Sarah Rotman. Microfinance and Mobile Banking: Blurring the Lines? Washington, DC: Consultative Group to Assist the Poor (CGAP), 2013.

Imai, Katsushi S., Thankom Arun, and Samuel Kobina Annim. Microfinance and Household Poverty Reduction: New Evidence from India. Vol. 38, Issue 12, World Development, 1760-1774. Elsevier, 2010.

Imai, Katsushi S., and Md. Shafiul Azam. Does Microfinance Reduce Poverty in Bangladesh? New Evidence from Household Panel Data. Vol 48, Issue 5, Journal of Development Studies, 633-653. 2012. 
Islam, Asadul, and Chongwoo Choe. Child Labor and Schooling Responses to Access to Microcredit in Rural Bangladesh. Vol.51, Issue 1, Economic Inquiry, 46-61. Western Economic Association International, 2013.

Islam, Asadul, and Pushkar Maitra. Health Shocks and Consumption Smoothing in Rural Households: Does Microcredit Have a Role to Play? Vol. 97, Issue 2, Journal of Development Economics, 232-243. Elsevier, 2012.

Karlan, Dean, and Martin Valdivia. Teaching Entrepreneurship: Impact of Business Training on Microfinance Clients and Institutions. Vol. 93, Issue 2, Review of Economics and Statistics, 510-527. Boston: MIT Press for the John F. Kennedy School of Government, 2011.

Khandker, Shahidur R., and Hussain A. Samad. Dynamic Effects of Microcredit in Bangladesh, Policy Research Working Paper. Washington, DC: World Bank, 2014.

Khandker, Shahidur R. Microfinance and Poverty: Evidence Using Panel Data from Bangladesh. Vol. 19, World Bank Economic Review, 263-286. Washington, DC: World Bank, 2005.

Khandker, Shahidur R. Fighting Poverty with Microcredit: Experience in Bangladesh. New York: Oxford University Press, 1998.

Klapper, Leora, Annamaria Lusardi, and Peter van Oudheusden. Financial Literacy Around the World: Insights from the Standard and Poor's Rating Services Global Financial Literacy Survey. 2014.

Kumar, Kabir, Claudia McKay, and Sarah Rotman. Microfinance and Mobile Banking: the Story So Far. Washington, DC: Consultative Group to Assist the Poor (CGAP), 2010.

Maldonado, Jorge H., and Claudio González-Vega. Impact of Microfinance on Schooling: Evidence from
Poor Rural Households in Bolivia. Vol. 36, Issue 11, World Development, 2440-2455. Elsevier, 2008.

Metre, Kanika. Using Mobile Banking Services to Improve Financial Access for the Poor: Lessons from Kenya, the Philippines, the United States, Haiti and India. Vol. 18, Policy Perspectives, 6-24. Washington, DC: The George Washington University, 2011.

McKernan, Signe-Mary. The Impact of Microcredit Programs on Self-Employment Profit: Do noncredit Program Aspects Matter? Vol. 84, Issue 1, Review of Economics and Statistics, 93-115. Boston: MIT Press for the John F. Kennedy School of Government, 2002.

MIMOSA. Microfinance Index of Market Outreach and Saturation: Cambodia. MIMOSA Project, 2016.

Morduch, Jonathan. Does Microfinance Really Help the Poor? New Evidence from Flagship Programs in Bangladesh. 1998.

Phim, Runsinarith. The Impacts of Microcredit on Poverty Reduction - Evidence from Cambodian Rural Villages. Vol. LI, No.2, The Philippine Review of Economics, 121 150. Quezon: University of the Philippines School of Economics and the Philippine Economic Society, 2014.

Pitt, Mark M., and Shahidur R. Khandker. The Impact of Group-based Credit Program on Poor Households in Bangladesh: Does the Gender of Participants Matter? Issue 106, Journal of Political Economy, 958-996. Chicago: University of Chicago Press, 1998.

Pitt, Mark M. and Shahidur R. Khandker. Household and Intrahousehold Impact of the Grameen Bank and Similar Targeted Credit Programs in Bangladesh. Washington DC: World Bank, 1996.

Pitt, Mark M., Shahidur R. Khandker, Signe-Mary McKernan, and M. Abdul Latif. Credit Programs for the Poor and Reproductive Behaviors in Low Income Countries: Are the Reported Causal Relationships 
the Result of Heterogeneity Bias? Vol. 36, No. 1, Demography, 1-21. 1999.

Pitt, Mark M., Shahidur R. Khandker, and Jennifer Cartwright. Empowering Women with Micro Finance: Evidence from Bangladesh. Vol. 54 No. 4, Economic Development and Cultural Change, 791-831. Chicago: University of Chicago Press. 2006.

Roodman, David, and J. Morduch. The Impact of Microcredit on the Poor in Bangladesh: Revisiting the Evidence. Washington, DC: Center for Global Development, 2009.

Roth, Vathana, Abdelkrim Araar, Bopharath Sry, and Dalis Phann The Dynamics of Microcredit Borrowings in Cambodia. Partnership for Economic Policy, Working Paper 2017-17, Nairobi: 2016.

Seng, Kimty. Rethinking the Effects of Microcredit on Household Welfare in Cambodia. In Journal of Development Studies. 2017.

Vietnam Microfinance Working Group. Bulletin Microfinance Regulation in Vietnam, No. 19. 2013.

World Bank. Finance for All? Policies and Pitfalls in Expanding Access. Washington, DC: World Bank, 2008.

World Bank. Improving Macroeconomic and Financial Resilience, Cambodia Economic Update. Washington, DC: World Bank, 2016.

World Bank. The Global Findex Database: Measuring Financial Inclusion and the Fintech Revolution. Washington, DC: World Bank, 2017. 


\section{Annex 1: Regression Results}

Table 3. The Characteristics of Formal and Informal Borrowers (Probit model)

\begin{tabular}{|c|c|c|c|}
\hline & \multicolumn{3}{|c|}{$1=$ formal borrower } \\
\hline & Cambodia & Urban & Rural \\
\hline Household size & $0.070^{\star \star \star}$ & $0.094^{\star \star \star}$ & $0.063^{\star \star \star}$ \\
\hline Dependent ratio & $-0.048^{\star *}$ & $-0.114^{\star \star}$ & -0.036 \\
\hline Household gender (1=male) & -0.060 & -0.040 & -0.060 \\
\hline Household age (years) & $0.007^{\star \star \star}$ & 0.003 & $0.008^{\star \star \star}$ \\
\hline Household marital status ( $1=$ married) & $0.139^{\star \star}$ & 0.150 & $0.143^{*}$ \\
\hline Household ethnic (1=Khmer) & $0.613^{\star \star \star}$ & 0.231 & $0.690^{\star * *}$ \\
\hline \multicolumn{4}{|l|}{ Education (reference category=no schooling) } \\
\hline Household education (1=primary incomplete) & $-0.239^{\star \star}$ & $-0.287^{\star \star}$ & -0.168 \\
\hline Household education (1=primary completed) & -0.089 & -0.214 & -0.003 \\
\hline Household education ( 1 =secondary completed) & -0.147 & -0.195 & -0.084 \\
\hline \multicolumn{4}{|l|}{ Occupation (reference category=unemployed/retired) } \\
\hline Household occupation (1=agriculture) & 0.031 & $-0.287^{\star \star}$ & $0.130^{\star \star}$ \\
\hline Household occupation (1=industry) & $0.223^{\star \star \star}$ & -0.103 & $0.322^{\star * *}$ \\
\hline Household occupation (1=service) & $0.280^{\star \star \star}$ & -0.110 & $0.422^{\star \star \star}$ \\
\hline Log of agricultural land (ha) & -0.028 & 0.030 & -0.031 \\
\hline \multicolumn{4}{|l|}{ Other control variables } \\
\hline Urban-Rural dummy & Yes & & \\
\hline Geographical dummy & Yes & Yes & Yes \\
\hline Year dummy & Yes & Yes & Yes \\
\hline
\end{tabular}


Table 4. Summary Estimate Results of Welfare Effects (one-to-five matching)

\begin{tabular}{|c|c|c|c|c|c|}
\hline & 2009 & 2012 & 2014 & 2015 & 2016 \\
\hline \multicolumn{6}{|l|}{ Household enterprise (Ioan access) } \\
\hline \% households engaged in non-agricultural activities & $5.68^{\star \star \star}$ & $6.62^{\star \star \star}$ & $8.11^{\star * \star}$ & $4.93^{\star *}$ & $5.88^{\star \star \star}$ \\
\hline \multicolumn{6}{|l|}{ Household shock (loan access) } \\
\hline Health expenditure per capita (ill members) (\%) & $11.55^{\star \star}$ & $19.53^{\star \star \star}$ & $25.89^{\star \star \star}$ & $29.60^{\star \star \star}$ & $21.76^{\star \star \star}$ \\
\hline \multicolumn{6}{|l|}{ Welfare (loan access) } \\
\hline Food consumption per capita per day (\%) & 2.2 & -3.04 & $-3.52^{\star \star \star}$ & 3.1 & 1.37 \\
\hline Nonfood consumption per capita per day (\%) & $8.06^{\star \star \star}$ & 5.2 & $8.03^{\star \star \star}$ & $9.56^{\star \star \star}$ & $11.14^{\star \star \star}$ \\
\hline Total consumption per capita per day (\%) & $3.70^{\star \star}$ & -1.05 & 4.57 & $5.88^{\star \star \star}$ & $5.89^{\star \star \star}$ \\
\hline Poverty rate (\%) & $-2.67^{\star}$ & -3.1 & -0.11 & $-4.89^{\star \star \star}$ & $-2.77^{\star \star}$ \\
\hline Poverty gap (\%) & $-1.56^{\star \star \star}$ & -0.83 & -0.26 & $-1.32^{\star \star \star}$ & $-1.06^{\star \star \star}$ \\
\hline \multicolumn{6}{|l|}{ Agricultural activities (actual loan) } \\
\hline Agricultural inputs (\%) & $4.65^{\star \star \star}$ & $12.87^{\star}$ & $11.98^{\star \star \star}$ & $16.56^{\star \star}$ & $28.33^{\star \star \star}$ \\
\hline Agricultural income per capita per month (\%) & 0.3 & 1 & $-10.08^{\star \star *}$ & -1.5 & -3.46 \\
\hline
\end{tabular}

Table 5. International Comparison of Efficiency

\begin{tabular}{|c|c|c|c|c|c|c|c|c|c|c|c|c|}
\hline & \multicolumn{12}{|c|}{ Efficiency (median) } \\
\hline & \multicolumn{6}{|c|}{ Operating Expense/GLP } & \multicolumn{6}{|c|}{ Cost per borrower (USD) } \\
\hline & 2012 & 2013 & 2014 & 2015 & 2016 & 2017 & 2012 & 2013 & 2014 & 2015 & 2016 & 2017 \\
\hline World & 16.2 & 17.0 & 18.3 & 17.4 & 15.1 & $\mathrm{~N} / \mathrm{A}$ & 156 & 167 & 181 & 169 & 156 & $\mathrm{~N} / \mathrm{A}$ \\
\hline South Asia & 10.9 & 11.5 & 10.9 & 9.2 & 9.3 & $\mathrm{~N} / \mathrm{A}$ & 18 & 19 & 21 & 21 & 21 & $\mathrm{~N} / \mathrm{A}$ \\
\hline $\begin{array}{l}\text { East Asia and the } \\
\text { Pacific }\end{array}$ & 12.5 & 18.3 & 18.1 & 17.0 & 16.3 & $\mathrm{~N} / \mathrm{A}$ & 64 & 87 & 105 & 98 & 131 & $\mathrm{~N} / \mathrm{A}$ \\
\hline Cambodia - MDls & 12.2 & 11.0 & 9.7 & 7.9 & 8.5 & 6.7 & 107 & 111 & 126 & 125 & 145 & 141 \\
\hline Cambodia - MFls & 14.1 & 13.7 & 11.2 & 12.5 & 13.0 & 14.3 & 290 & 241 & 204 & 296 & 526 & 635 \\
\hline
\end{tabular}

Note: GLP=Gross Loan Portfolio. N/A= Not available.

Source: Authors' calculations using Mix Market and National Bank of Cambodia data. 
Figure 9. Efficiency among MDls have increased over the past two years, whereas it declined for MFIs

Efficiency score, weight average

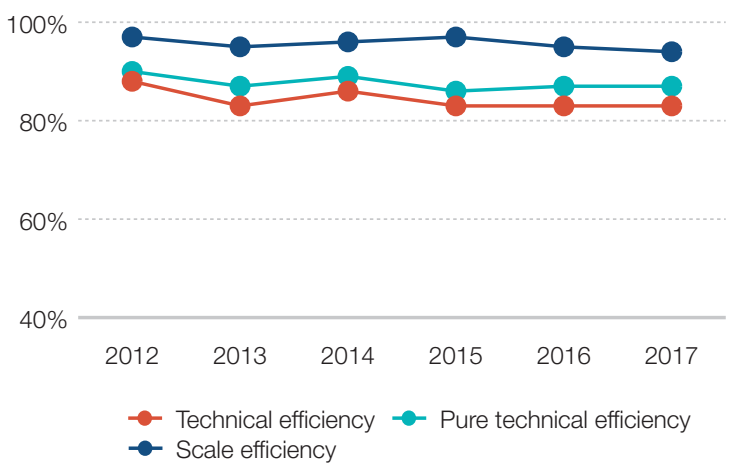

CRS-Technical Eefficiency, weight average



Source: Authors' calculation using National Bank of Cambodia data. Note: CRS: Constant return to scale.

Table 6. The Determinants of Microfinance Efficiency - Zero Inflated Beta Regression Model

\begin{tabular}{|c|c|c|c|c|c|c|}
\hline & \multicolumn{3}{|c|}{ Proportion } & \multicolumn{3}{|c|}{ One Inflate } \\
\hline & CRS_TE & VRS_TE & SCALE & CRS_TE & VRS_TE & SCALE \\
\hline Foreign ownership & -0.003 & -0.002 & -0.002 & 0.006 & 0.006 & 0.006 \\
\hline Loan per staff & $2.966^{\star \star \star}$ & $4.274^{\star \star \star}$ & 0.405 & $7.837^{\star \star \star}$ & $9.563^{\star \star \star}$ & $7.837^{\star \star \star}$ \\
\hline Loan size (log) & $-0.623^{\star \star \star}$ & $-0.592^{\star \star \star}$ & $-0.406^{\star \star \star}$ & $-2.651^{\star \star *}$ & $-2.512^{\star \star \star}$ & $-2.651^{\star \star \star}$ \\
\hline Asset (log) & $0.508^{\star \star}$ & $0.556^{\star *}$ & 0.09 & $1.566^{\star \star}$ & $2.369^{\star \star \star}$ & $1.566^{\star \star}$ \\
\hline Equity (log) & $0.694^{*}$ & $0.775^{\star}$ & 0.461 & $2.600^{*}$ & $2.530^{\star}$ & $2.600^{\star}$ \\
\hline Interest expense (log) & 0.002 & -0.035 & $0.080^{\star \star}$ & $-0.544^{\star * \star}$ & $-0.568^{\star * \star}$ & $-0.544^{\star * \star}$ \\
\hline Operating expense (log) & $-0.701^{\star * *}$ & $-0.860^{\star \star \star}$ & 0.035 & $-1.548^{\star \star}$ & $-2.642^{\star \star \star}$ & $-1.548^{\star \star}$ \\
\hline Borrower density & 1.003 & $1.742^{\star \star \star}$ & -1.223 & $4.921^{\star \star \star}$ & $5.145^{\star \star \star}$ & $4.921^{\star \star \star}$ \\
\hline Constant & $3.982^{\star \star \star}$ & $4.166^{\star \star \star}$ & $4.257^{\star \star \star}$ & $19.133^{\star \star \star}$ & $17.066^{\star \star \star}$ & $19.133^{\star \star \star}$ \\
\hline
\end{tabular}

Note: Dependent variable is technical efficiency scores based on constant return to scale. Similar results are obtained when estimates are based on variable returns to scale technical efficiency scores.

Source: Authors' calculation using National Bank of Cambodia data. 
Figure 10. Loan by sector reported by MFls/MDls

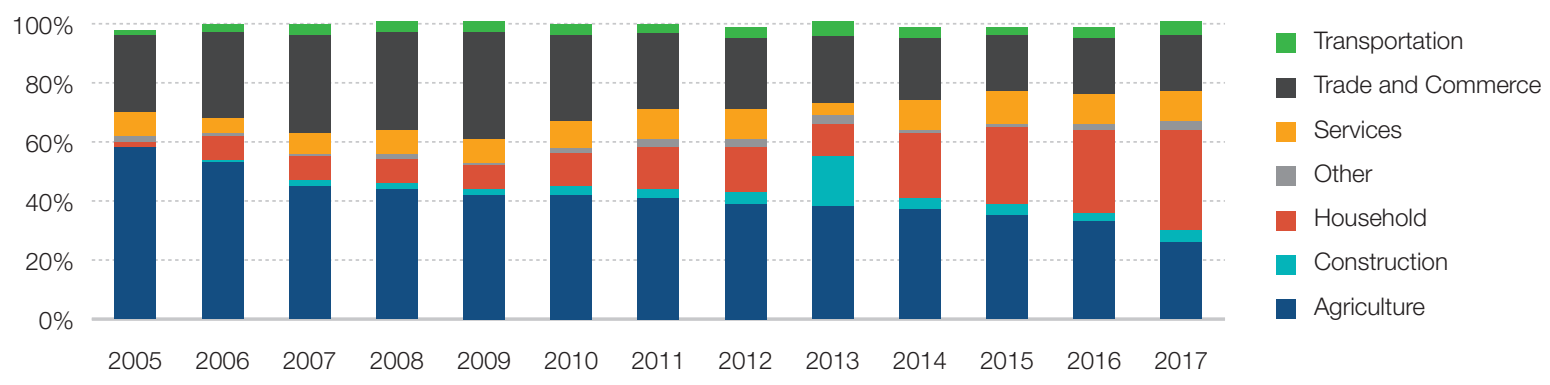

Source: Authors' calculation using National Bank of Cambodia data.

Table 7: The effects of interest rate cap on microfinance sector by MDIs and MFls

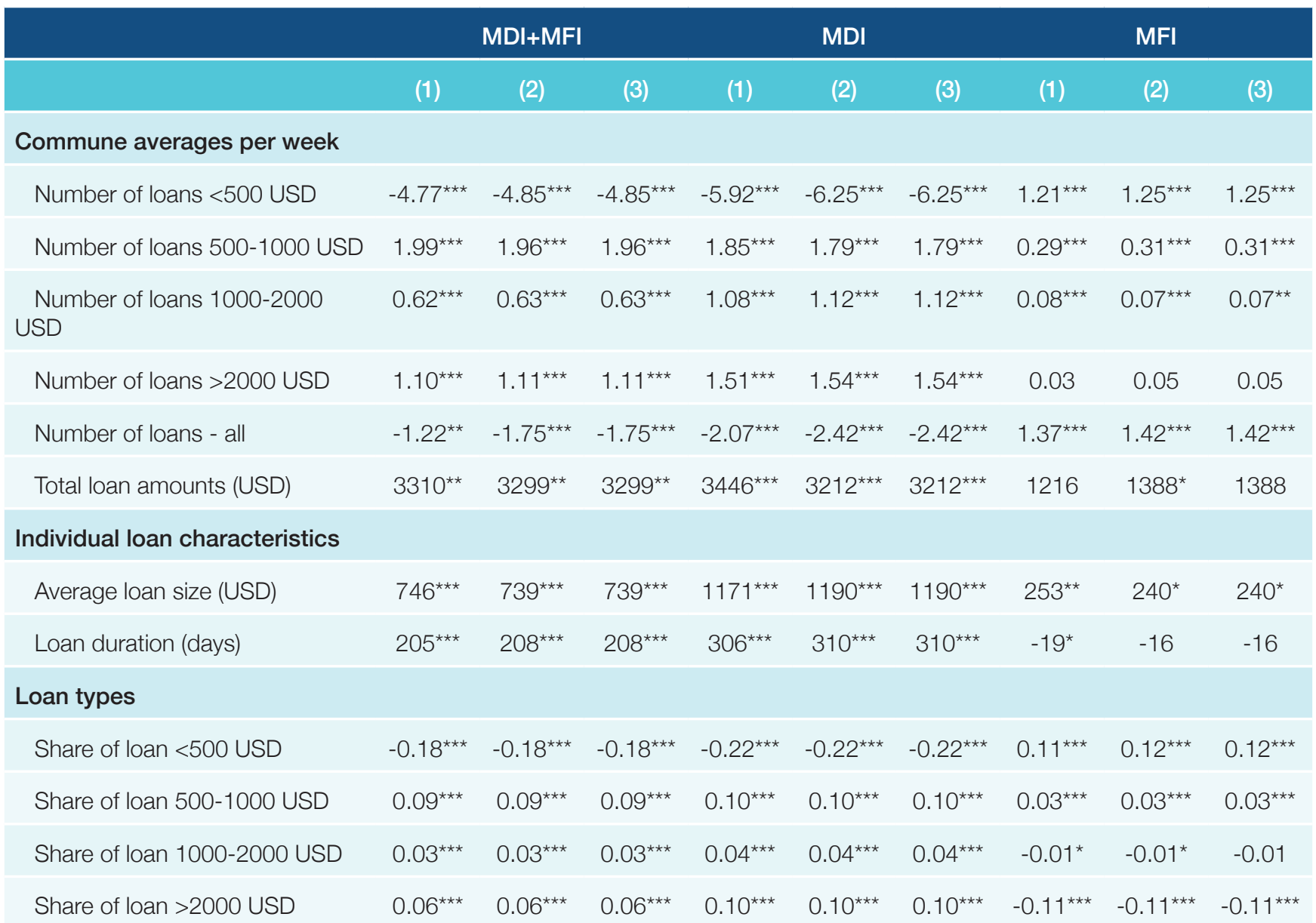

Source: Authors' calculation using Credit Bureau Cambodia Data.

Note: The control variables included borrower characteristics such as age, gender, and self-employed; urban area; ${ }^{a}$ and the number of holidays. The results presented in Table 1 are those with polynomial order 2 option. Those with polynomial order 3 option are not reported. The main text discusses those results that are consistent. (1) = Conventional. (2) = Bias-corrected. $(3)=$ Robust

a. Urban area is defined at the district level within each province, i.e. one district per province. This definition is not in line with that of the National Institute of Statistics (NIS), which defines urban/rural area at the commune level. If the analysis used the NIS definition to identify urban/rural, a certain number of communes were unidentified, and those communes accounted for 35 percent of total loan portfolio in each year. This amount was too big to exclude from the analysis. 


(4) WORLD BANK GROUP

Cambodia Country Office

Exchange Square Building

Floor 10th IBRD and 11th IFC

Streets 51-61 and streets 102-106

Sangkat Wat Phnom, Khan Daun Penh

Phnom Penh, Cambodia

www.worldbank.org/cambodia 